\title{
21 Botryllus schlosseri-A Model Colonial Species in Basic and Applied Studies
}

\author{
Oshrat Ben-Hamo and Baruch Rinkevich
}

\section{CONTENTS}

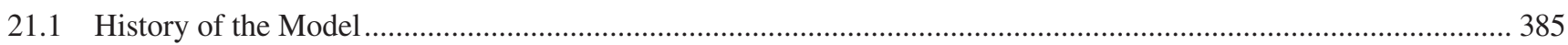

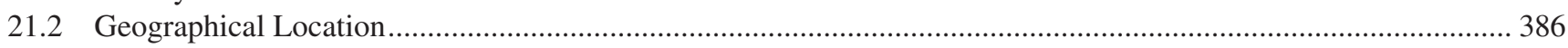

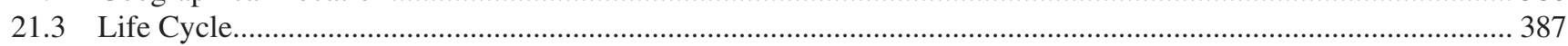

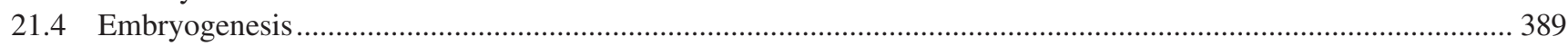

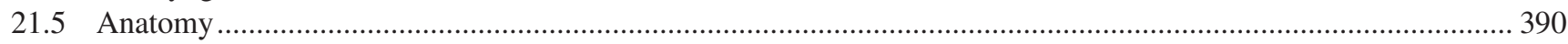

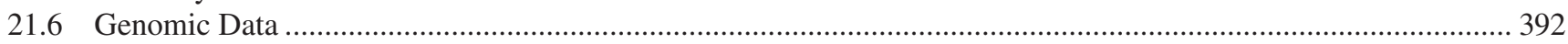

21.7 Functional Approaches: Tools for Molecular and Cellular Analyses....................................................................... 393

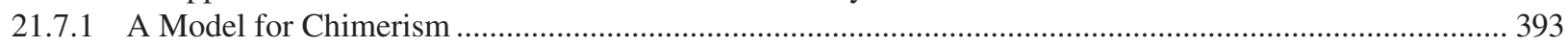

21.7.2 Accessible Regeneration/Aging Stem Cell-Mediated System ........................................................... 394

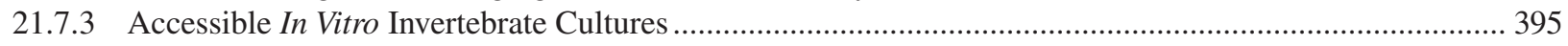

21.8 Challenging Questions Both in Academic and Applied Research ................................................................... 395

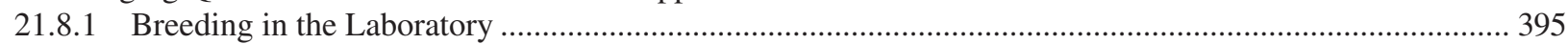

21.8.2 Lack of Sufficient Molecular Research Tools ....................................................................................... 395

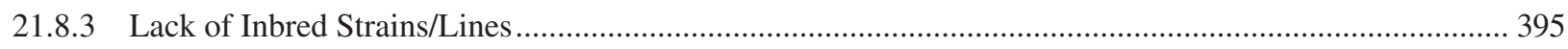

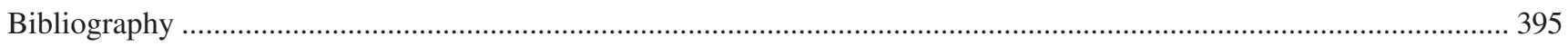

\subsection{HISTORY OF THE MODEL}

The apparent first description of Botryllus schlosseri colonies is attributed to Rondelet Guillaume (1555), under the name uva marina. With the increased interest in this species, about two centuries later, Botryllus was re-described by J.A. Schlosser and J. Ellis in a letter (1756) as: "I discovered a most extraordinary sea-production surrounding the stem of an old fucus teres [a brown algae]: it was of a hardish, but fleshy substance ... of a light brown or ash colour, the whole surface covered over with bright yellow shining and star-like bodies". Later the animal was portrayed by Pallas (1766) as a zoophyte, that is to say, an animal-plant, and was named by Pallas Alcyonium schlosseri Pallas (1766). Linnaeus (1767) defined Botryllus as a soft coral from the family Alcyoniidae (Pallas 1766; Linnaeus 1767). Following these authors, Gärtner, Bruguière and Renier ascribed the animal as Botryllus stellatus (Gärtner 1774; Bruguière 1792; Renier 1793), and in 1816, the animal got its permanent name: Botryllus schlosseri (Savigny 1816). In a comprehensive review on this species, Manni et al. (2019) covered a list of authors who described Botryllus during the 19th century, and it will not be repeated here. Many of these papers were written in local languages (Italian, German, French) and the most comprehensive, as pioneering studies on Botryllus, are those published by Savigny (1816), Ganin (1870), Giard (1872) and Della Valle (1881). The famous biologist, zoologist and gifted painter Ernst Haeckel (1899) created a known drawing of Botryllus including anatomy.
The first biologist who successfully grew and bred Botryllus schlosseri colonies in the lab was Sabbadin in 1955. This opened a door for other laboratories to adopt Botryllus as a model in their studies. For the past decades, three main laboratories have been investigating and focusing on Botryllus schlosseri. These labs are located in California, United States (Weissman's lab); Italy (Sabbadin, Ballarin and Manni's labs); and Israel (Rinkevich's Lab). Several important milestones in the history of this species deal with the Botryllus palleal budding (asexual reproduction), whole body regeneration and allorecognition. The first study that described the complex weekly budding process in this species and the life and death cycles of Botryllus zooids (blastogenesis) was Spallanzani (1784). Important milestones in the study of bud development and life-and-death cycles were published by Metschnikow (1869), Hjort (1893) and Pizon (1893), Berrill (1941a, 1941b, 1951), Watterson (1945), Sabbadin (1955) and Izzard (1973). Also, the phenomenon of whole-body regeneration (vascular budding) in Botryllus was reported by Ganin (1870) and followed by Giard (1872) and Herdman (1924).

For allorecognition, the first documentation for fusion/ rejection phenomena between contacting Botryllus colonies (self/non-self recognition) was made by Bancroft (1903). Only six decades thereafter, basic genetic studies and searches for allorecognition properties were followed by Sabbadin (1962) and Scofield et al. (1982) focusing on Botryllus schlosseri, while other studies evaluated allorecognition in Botryllus primigenus (Oka and Watanabe 1957, 1960; Taneda and Watanabe 1982a, 1982b; Taneda et al. 1985). Results were 
intensified following the establishment of allorecognition assays (Rinkevich 1995) and animal breeding methodologies (Brunetti et al. 1984; Boyd et al. 1986; Rinkevich and Shapira 1998). Other studies on allorecognition contributed
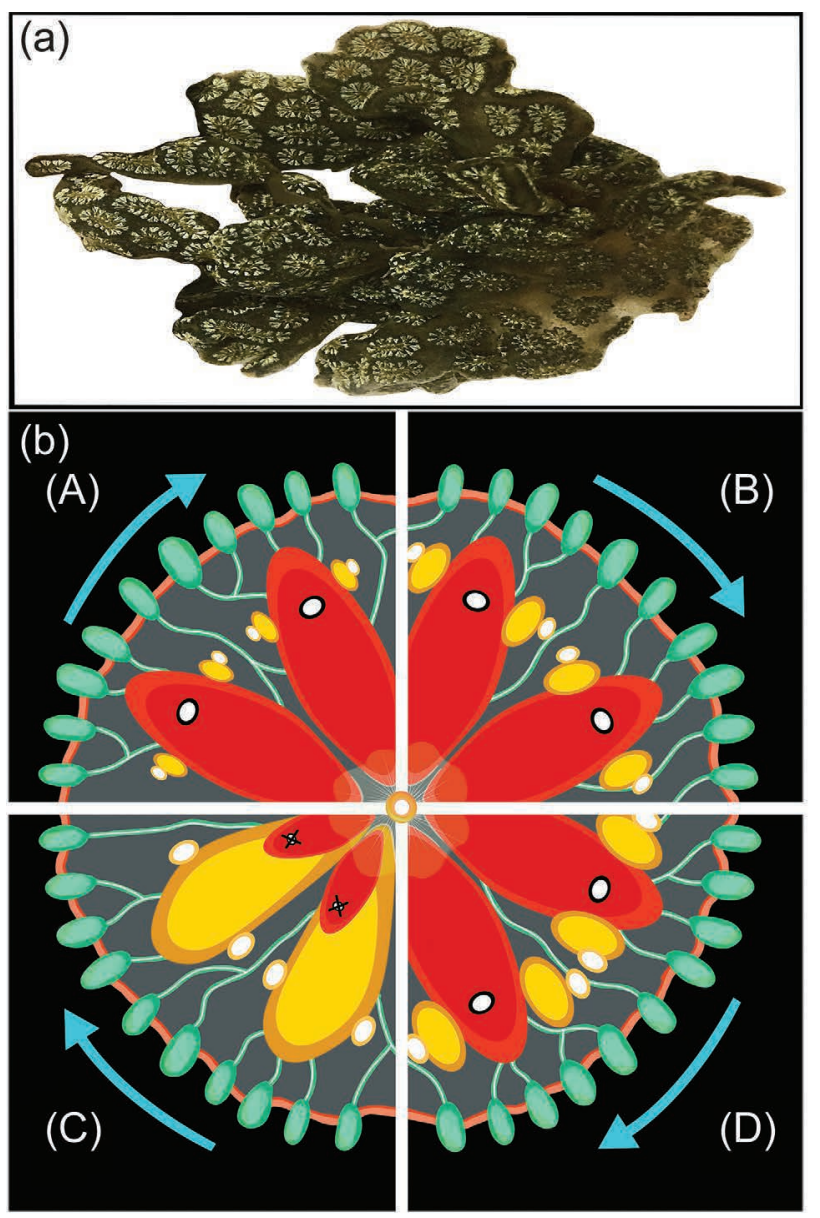

FIGURE 21.1 (a) A colony of Botryllus schlosseri (ca, $7 \mathrm{~cm}$ length) collected from a Chioggia, Italy, harbor, which naturally grow on algae as substrates. The colony is composed of hundreds of zooids arranged in colonial systems. (b) A diagram representing the four blastogenic stages that typify a weekly cycle (ca. seven days long). The green extensions represent the peripheral ampullae and their attached vasculature. Three generations of modules are shown in each stage: the mature zooids are colored in red, the primary buds in yellow and the secondary buds in white. Stage A, the beginning of a cycle, is signified by the opening of the oral and atrial siphons of the zooids. Open siphons enable the zooids to feed and breed. Secondary buds evaginate from the atrial wall of the primary buds. Primary buds are small and non-functional. Stage B is signified by visible heart-beats in the primary buds, while secondary buds develop as closed double-layered structures. In Stage C, primary buds almost complete development, while secondary buds commence organogenesis, primary subdivisions are completed and pigment cells accumulate in their outer epithelium. Stage D (takeover) starts by closing of the zooids' siphons and their continuous shrinkage until completely resorbed. At the same time the primary buds complete their development and are now fully grown, "waiting" for the takeover stage to conclude so that their oral siphons will be opened in the beginning of a new blastogenic cycle, enabling them to feed and breed. ([a-d] sensu Watanabe 1953 and Lauzon et al. 2002.) to the understanding of the initiation, the follow-up and the biology of chimerism; the involvement of stem cells in the process; and stem cell parasitism (e.g. Scofield et al. 1982; Rinkevich et al. 1993, 2013; Stoner and Weissman 1996; Stoner et al. 1999; Laird et al. 2005a; Corey et al. 2016).

Additional milestones in the research on Botryllus schlosseri are the publication of its draft genome, followed by the sequence of the histocompatibility locus (Voskoboynik et al. 2013a, 2013b).

\subsection{GEOGRAPHICAL LOCATION}

The colonial tunicate Botryllus schlosseri (Figure 21.1a, Figure 21.3) is a common shallow-water marine species, found from the intertidal zone to $200 \mathrm{~m}$ depth, above and under stones; on natural hard substrates; on algae and seaweeds; and on artificial substrates such as pilings, floats, pontoons, wharfs, ropes and ship bottoms (Rinkevich and Weissman 1991; Müller et al. 1994; Rinkevich et al. 1998a, 1998b), as well as on motile macroinvertebrates (Bernier et al. 2009) and on fish (Kayiş 2011). This species probably originated in the Atlantic European and Mediterranean seas (Van Name 1945; Berrill 1950; Paz et al. 2003; LópezLegentil et al. 2006) and spread globally (Figure 21.2). Traits like fast adaptation to human-made environmental conditions (Lambert 2001; Lambert and Lambert 2003) and assumed high mutation rates acted as surrogates for the increase of genetic variability in just-established populations (Reem et al. 2013a). This further promotes the species invasiveness capacities by assisting pioneering colonies in quickly spreading in new sites and then their fast integration as common participants in assemblages of hard-bottom consortia (Lambert and Lambert 1998, 2003; Locke et al. 2009; Martin et al. 2011).

$B$. schlosseri is primarily recorded in marinas and harbors in the northern and southern hemispheres and has become a cosmopolitan alien species in marine human-made submerged hard substrates (Figure 21.2) (Rinkevich et al. 1998a, 1998b, 2001; Ben-Shlomo et al. 2001, 2006, 2010; Stoner et al. 2002; Paz et al. 2003; Bock et al. 2012; Reem et al. 2013a, 2013b, 2017; Yund et al. 2015; Karahan et al. 2016; Nydam et al. 2017). In the northern hemisphere, populations of B. schlosseri are distributed in all Atlantic coasts from the southern coast of India (Meenakshi and Senthamarai 2006; $8^{\circ} 22^{\prime} \mathrm{N}$ latitude, where sea water temperature ranges from 24 to $\left.29.5^{\circ} \mathrm{C}\right)$, to the Norwegian sea ports $\left(>62^{\circ} \mathrm{N}\right)$ with sea water temperatures ranging between 3 and $17^{\circ} \mathrm{C}$, up to Alaska on the west coast of North America and British Columbia, Canada, and the east coast (Epelbaum et al. 2009), Japan (Rinkevich and Saito 1992; Rinkevich et al. 1992a), Korea and more (Figure 21.2). Populations of this species are further thriving under wide salinity ranges (18-34\%; Epelbaum et al. 2009). In the southern hemisphere, this species is thriving in New Zealand (Ben-Shlomo et al. 2001), Australia and Tasmania (Kott 2005), South Africa (Millar 1955; Simon-Blecher 2003), Chile and Argentina (Figure 21.2) (Orensanz et al. 2002; Castilla et al. 2005; Ben-Shlomo 


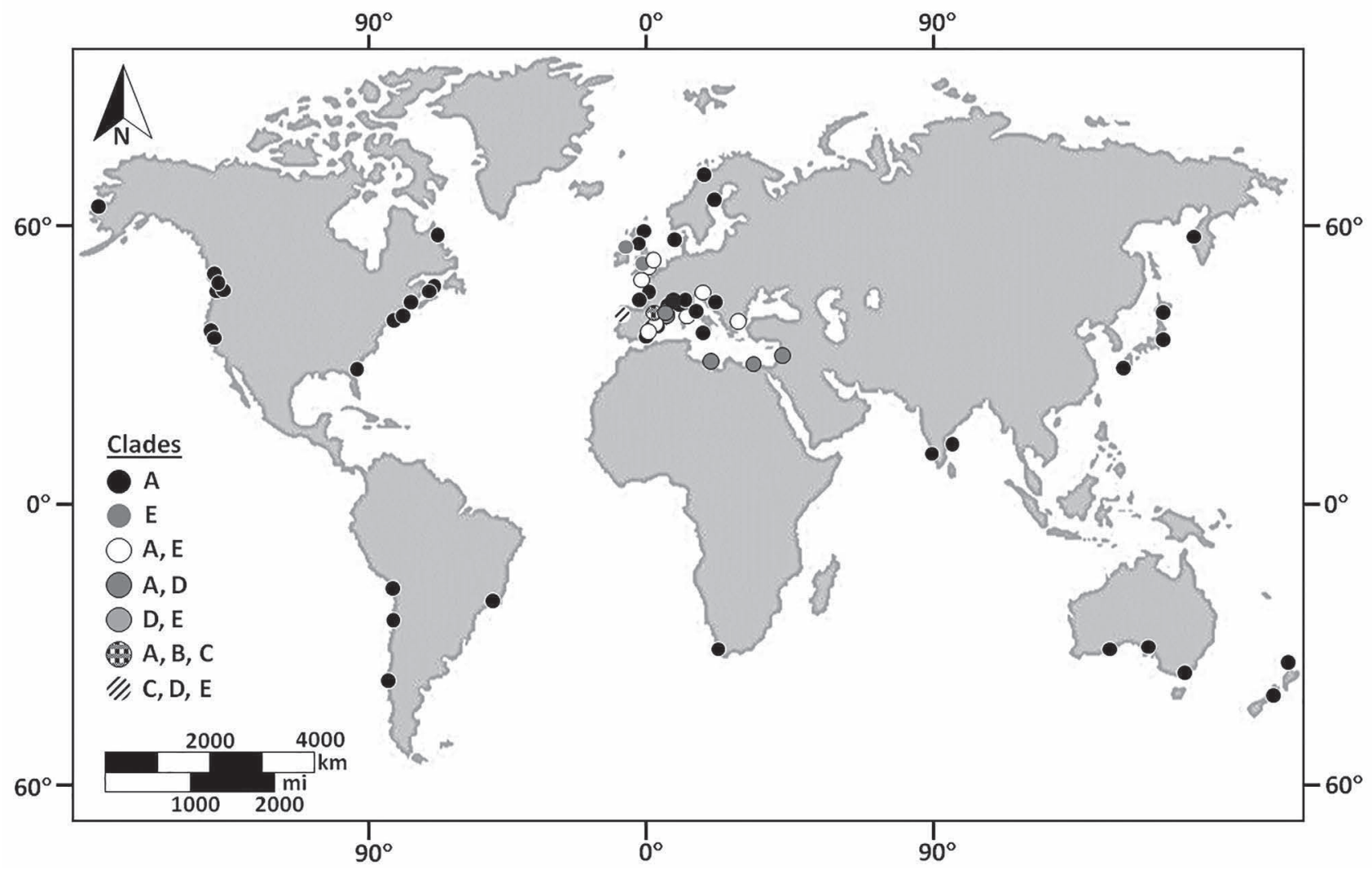

FIGURE 21.2 Global distribution of the Botryllus schlosseri five clades (a to e). The global distribution has been contributed by anthropogenic factors (see geographical location section). (Graphic assistance by Guy Paz.)

et al. 2010). Early suggestions (e.g. Van Name 1945) have implied that B. schlosseri originated in European waters, a proposal supported by Reem et al. (2017), while Yund et al. (2015) proposed that at least one haplotype in clade A (see the following) is native to the northwest Atlantic. Carlton (2005) proposed, albeit without supporting documentation, a possible Pacific origin. It is further assumed that this worldwide distribution pattern of $B$. schlosseri is primarily anthropogenic in nature, initiated during the last millennium with European travelers who sailed and explored the world, and further enhanced by aquaculture activities (Fitridge et al. 2012; Carman et al. 2016).

The use of the cytochrome oxidase subunit I (COI) marker for B. schlosseri population structures worldwide has resulted in the detection of five highly divergent $B$. schlosseri clades (termed A-E), leading to the assumption that $B$. schlosseri is a complex of five cryptic, and probably reproductively isolated, species (Bock et al. 2012). Yet Reem et al. (2017) revealed the possibility of admixture between individuals from clades $\mathrm{A}$ and $\mathrm{E}$ within two $B$. schlosseri Mediterranean populations, challenging this assumption. Clade A has emerged as a cosmopolitan, revealing significant differentiation patterns between native and invasive populations (Bock et al. 2012; Lin and Zhan 2016). The other four COI clades are restricted to the Mediterranean Sea and Atlantic European waters, with the wider distribution of clade $\mathrm{E}$ that is recorded from both sides of the La
Manche channel and many coasts in the Mediterranean Sea, and clades B, C and D that are confined to a restricted few harbors (Figure 21.2). B. schlosseri clade B was found only in a single site, Vilanova, Spain, and in few samples (LópezLegentil et al. 2006). B. schlosseri clade $\mathrm{C}$ was found in just three sites (López-Legentil et al. 2006; Pérez-Portela et al. 2009). López-Legentil et al. (2006) recorded few clade C specimens from Vilanova and Fornelos. Pérez-Portela et al. (2009) collected three samples from Ferrol, $7 \mathrm{~km}$ from Fornelos. This scarcity of data prevents the drawing of further conclusions.

\subsection{LIFE CYCLE}

The life cycle of the Botryllus colony reveals a complex astogeny (building of a colony body) where the continuous and synchronous exchange of asexual-derived generations of basic modules (the zooids in botryllid ascidians) takes place on a weekly basis, a phenomenon of cyclical death and rebirth that is called blastogenesis (Figure 21.1b) (Rinkevich 2002a, 2019; Manni et al. 2007, 2014, 2019; Rinkevich et al. 2013; Tiozzo et al. 2005). Upon accomplishing ontogeny, the first established basic module (oozooid) (Figure 21.3b) then commences astogeny, where similarly sized modules are continuously added in blastogenesis, a process also known as asexual reproduction (Figure 21.3c, d), dictated in B. schlosseri by synchronous and cyclical asexual 
multiplication processes; each lasts for about one week (Figure 21.1b) (Rinkevich 2002a, 2019; Manni et al. 2007, 2014, 2019). At the colony level, zooids are arranged in starshaped systems, each with a common cloacal siphon in the center, and when the colony expands, each colonial system divides into two or more systems, each centered by a cloacal siphon (Figure 21.3d). The continuous developmental process of colonial growth is thus repeatedly interrupted by this phoenix-like (Rinkevich 2019) death and rebirth cycles of old and new modules, respectively (Figure 21.1b).

A mature B. schlosseri colony contemporaneously accommodates three successive generations of modules at any given time throughout the colony's lifespan, the zooids and two generations of buds, all arranged in a hierarchical subdivision within the colony (Figure 21.1b, Figure 21.4). The colony increases in size when more than one bud replaces each zooid of the old generation. The mature functioning modules are the zooids; the most-developed sets of buds but not yet active modules are the primary buds; and the youngest generation, the just-budded modules (the budlets), are the secondary buds (Figure 21.4). The development and growth of the three generations of modules are highly synchronized so that all modules of a certain cohort are exactly at the same differentiating state (Figure 21.1b) (Milkman 1967). Although a colony can live for several months to years, the colonial modules are transient, and the life span of each module, from onset of secondary bud to morphological resorption of the mature zooid, is about three weeks (three blastogenic cycles), whereas the functionalzooid status is for just one week/blastogenic cycle (Figure 21.1b) (under $20^{\circ} \mathrm{C}$; Sabbadin 1955; Manni et al. 2007, 2019).

The budlets are formed and developed from the atrial wall (the peribranchial epithelium) of the primary buds as disc-shaped thickenings (Figure 21.4). The bud primordium curves perpendicularly to the primary bud wall and forms a small hemisphere and then tilts toward the anterior end of the primary bud, already establishing the anterior-posterior and dorsal-ventral axes (Sabbadin et al. 1975; Manni et al. 2007). At the end of the first week of the budlet's life, hearts are morphologically recognizable but do not function yet. Following the takeover stage (see the following) and along the second week of life, these modules become the primary buds, where additional organogenesis steps advance toward fully developed buds (Figure 21.4) (Berrill 1941a, 1941b; Izzard 1973). Following the next takeover stage and simultaneously at the beginning of the third and last week of the module's life, they become fully functional zooids, with open oral siphons, and are able to feed and breed (Figure 21.1b). All developmental stages of the three generations of modules are coordinated simultaneously, and the young zooids take over the colony from the older generation of zooids (morphologically illuminated by opening their oral siphons) simultaneously with the clearance and morphological absorption of the old zooids (Figure 21.1b) (Lauzon et al. 2000, 2002; Manni et al. 2007, 2014; Ballarin et al. 2010).

The takeover phase, 24-36 hours at the end of each blastogenic cycle, is the most dramatic astogenic process, where the old zooids gradually shrink and are absorbed into the colonial mass until completely disappearing (Lauzon et al. 1992, 2002; Manni et al. 2007; Ballarin et al. 2010). On the cellular level, the morphological clearance of the zooids is manifested by whole-zooid apoptosis and phagocytosis processes (Cima et al. 2003; Ballarin et al. 2010), and cell corpse clearance is assisted by hyaline amoebocytes and macrophage-like cells (Cima et al. 2003; Voskoboynik et al. 2002, 2004; Ballarin and Cima. 2005; Ballarin et al. 2008). Phagocyte digestion may lead to an oxidative stress, further enhancing zooidal senescence (Cima et al. 2010). Employing an anti-oxidant treatment (BHT) on the blastogenic cycle, Voskoboynik et al. (2004) have pointed to the importance of the macrophages in triggering apoptosis. The phagocyted materials are than recycled for other energy needs of the colony (Lauzon et al. 2002).

Two major staging methods associated with the complex development of the three module types within a single blastogenic cycle in botryllid ascidians were suggested (Watanabe 1953; Sabbadin 1955; modification of Sabbadin's method was suggested by Izzard 1973). The blastogenic cycle is either divided into four phases (Figure 21.1b) according to Watanabe (1953), or into 11 stages according to Sabbadin (1955). Each method has its pros and cons, and scientists use either method according to their research interests.

Few studies have searched for the molecular machinery controlling blastogenesis. One specific gene, Athena, was defined (Laird et al. 2005b) as differentially upregulated in the takeover stage as compared to the other blastogenic phases while being transcribed in the developing buds and absorbing zooids. Knockdown of the gene in Botryllus using RNAi and antisense morpholinos led to abnormal developmental syndromes of the buds. Further, the Botryllus homologue PL-10 also revealed a cyclical pattern associated with the blastogenic cycle with lower levels in old zooids as compared to young buds (Rosner et al. 2006). The same applies to 10 of the genes of the IAP family (a total of 25; Rosner et al. 2019) that were upregulated at late blastogenic stages $C$ and D (Figure 21.1b) concurrent with increased expressions of apoptosis-inducing genes (AIF1, Bax, MCl1) and three caspases (caspase 2 and two orthologues of caspase 7), as in the reorganization of the colonial architecture (Rinkevich et al. 2013; Rosner et al. 2006, 2013, 2019).

When considering the yet-unknown cellular and molecular pathways which control astogeny in B. schlosseri, it is of interest to evaluate the operation of astogeny-associated gene families, as the same gene families may be used in ontogeny (e.g. Rosner et al. 2014). One of the first genes used for such comparisons is Pitx (Tiozzo and De Tomaso 2009; Tiozzo et al. 2005), a developmental regulator involved in organ development and in left-right asymmetry (Boorman and Shimeld 2002; Hamada et al. 2002). The Botryllus Pitx was present in earlier stages of bud development with similar expression patterns as in the developing embryos, suggesting a parallel role in module/embryo development (Tiozzo et al. 2005; Tiozzo and De Tomaso 2009). Other transcription factors involved in bud development are FoxA1, GATAa, GATAb, Otx, Gsc and Tbx2/3 (Ricci et al. 2016a). 
Further research studied the expression along blastogenesis of three conserved signal transduction pathways, Wnt/ $\beta$ catenin, TGF- $\beta$ and MAPK/ERK (Rosner et al. 2014), by studying representative gene $\beta$-catenin (for $\mathrm{Wnt} / \beta$-catenin pathway), $\mathrm{p}-\mathrm{Smad} 2$ and $\mathrm{p}-\mathrm{Smad} 1 / 5 / 8$ (for TGF- $\beta$ pathway) and p-Mek1/2 (for MAPK/ERK pathway). Results revealed that while the same molecular machinery is functioning in Botryllus schlosseri astogeny and ontogeny, astogenic development is not an ontogenic replicate (Rosner et al. 2014).

Blastogenesis (Figure 21.1b) in B. schlosseri holds some unique characteristics for aging in colonial (modular) organisms that distinguishes this type of aging from aging in unitary organisms (Rinkevich 2017). Some characteristics that refer to non-random (genetic based) mortality were recorded in these organisms (Rinkevich et al. 1992b; Lauzon et al.
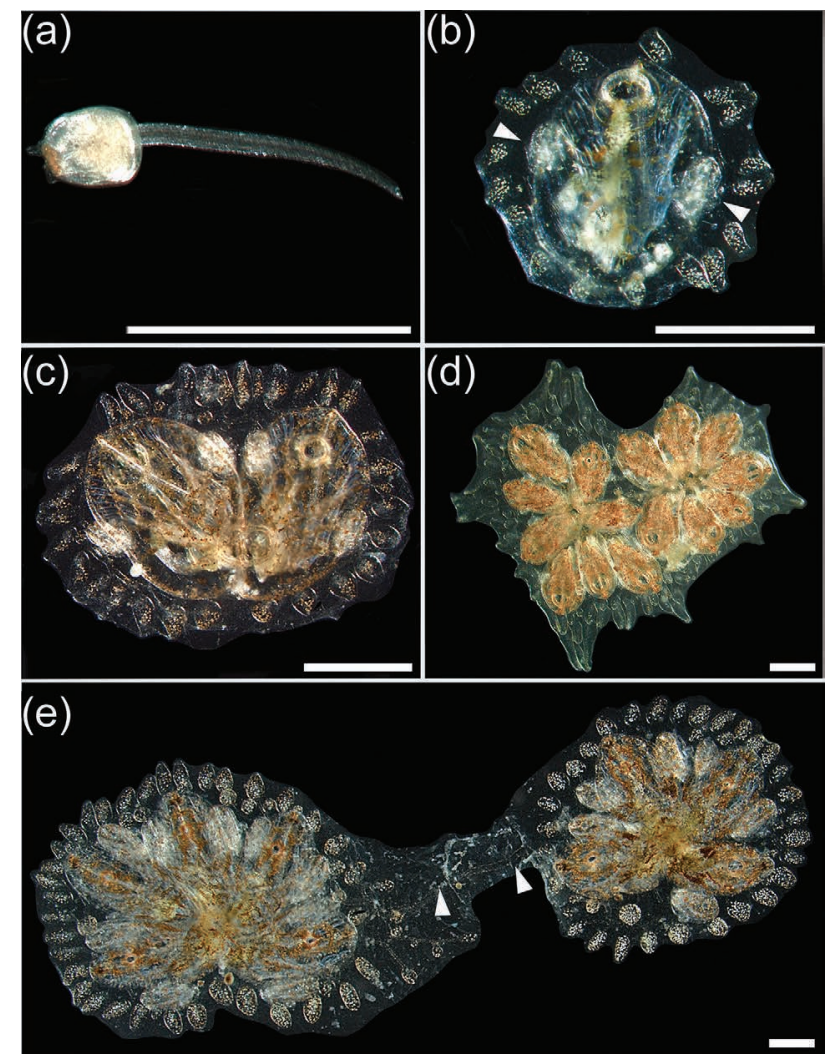

FIGURE 21.3 (a-d) Life stages of a Botryllus schlosseri colony. (a) Botryllus begins its life as a mobile larva, composed of a visceral trunk and locomotory tail. The mobility enables the larva to swim and find adequate substrate to settle on. (b) At metamorphosis, the attached larva becomes the first zooid, the oozooid, with open oral and atrial siphons. On both sides of the oozooid, the new generation of buds (white arrowheads) are formed and developed. (c) After a few days, the oozooid is resorbed and is replaced by two new zooids. (d) The numbers of zooids grows over time, forming a mature colony. The size of a colony differs between colonies and depends on the number of zooids (see colony in Figure 21.1a for comparison). (e) A chimera composed of two distinct colonies, connected via a blood vessel (two arrowheads). The chimera is formed after a physical contact between the ampullae of both of colonies (details in "Functional Approaches: Tools for Molecular and Cellular Analyses"). Scale bars $=0.5 \mathrm{~mm}$.
2000; Rabinowitz and Rinkevich 2004; Rinkevich 2017). The phenomena of budding, as well as module senescence, can be concurrently expressed at three hierarchical levels of colonial organization: the zooids, ramets and genets, including the weekly blastogenesis, the whole-genet programmed life span (Rinkevich et al. 1992b); ageing at the ramet level (Rabinowitz and Rinkevich 2004); and rejuvenilization after acute damage (Voskoboynik et al. 2002). To further understand Botryllus blastogenesis and aging at the molecular level, the aging-related heat-shock protein mortalin was studied (Ben-Hamo et al. 2018). RT-PCR and in-situ hybridization revealed significant upregulation of mortalin in colonies during the takeover phase as compared to other blastogenic phases. Quantitative PCR analyses of excised buds and zooids showed significantly higher levels of mortalin in buds as compared to functioning zooids. These findings are in line with literature that demonstrated lowering levels of mortalin in old organisms as compared to young organisms (Yokoyama et al. 2002; Kimura et al. 2007; Yaguchi et al. 2007), demonstrating a possible aging process that is restricted to the modules and associated with the blastogenic cycle (Ben-Hamo et al. 2018).

\subsection{EMBRYOGENESIS}

Like the rest of the many colonial tunicates and unlike the other chordates, Botryllus schlosseri is an ovoviviparous species (Zaniolo et al. 1987) that reproduces both asexually and sexually, and colonies are simultaneous hermaphrodites (Berrill 1950; Rodriguez et al. 2014). The colonies can randomly switch between male and hermaphrodite states following physiological stress or become sterile (Rodriguez et al. 2016). Yet self-fertilization is eliminated, as male gonads mature two days following the eggs' fertilization by foreign sperm (Milkman and Borgmann 1963; Milkman 1967; Mukai 1977). Nonetheless, self-fertilization was successfully achieved under laboratory conditions (Milkman and Borgmann 1963; Milkman 1967; Rinkevich 1993) and in the field after surgical or natural separation of a colony into systems (Sabbadin 1971; Gasparini et al. 2014), documenting that in the absence of foreign sperm, self-fertilization may occur. Late fertilization is prone to embryo resorption at blastogenesis stage D (the takeover phase) due to larval delayed development (Milkman 1967, Stewart-Savage et al. 2001). Following metamorphosis of the larva (Figure 21.3a) into the first established zooid (the oozooid) (Figure 21.3b), it takes between 8 and 12 blastogenic cycles for the male gonads to develop and mature (Sabbadin 1971; Sabbadin and Zaniolo 1979). The female gonads mature afterward, establishing the hermaphrodite type of $B$. schlosseri's sexual reproduction (Figure 21.4).

The gonads are first observed in the secondary buds. At onset, a bilateral gonad blastema appears where its medial part will give rise to the testis and the lateral part to the ovary. The oocytes and testes develop in the buds' blastema, and the oocytes move through several generations of buds (Sabbadin and Zaniolo 1979). Testes and ovaries are formed 
in the blastema and located in mesenchymal spaces between the epidermis and the peribranchial epithelium (Mukai 1977; Sabbadin and Zaniolo 1979). A study on the sister-species, Botryllus primigenius, showed that in cases where large oocytes inherited from former generations reach the blastema cell masses of the bud, part of the blastema is differentiated into the egg envelope, creating the egg follicle and a follicle stalk, while the other part of the blastema is differentiated into the testes. If ova are missing, the cell mass will differentiate into testes only (Mukai and Watanabe 1976). An ovary is composed of one to four oocytes (Zaniolo et al. 1987) of different sizes and developmental stages (Sabbadin and Zaniolo 1979) and contains a variable number of undifferentiated cells (Sabbadin and Zaniolo 1979). The globular egg that is enclosed within the ovum is layered by the chorion (acellular vitelline coat or egg-membrane) and the inner and outer follicle cell layers (Zaniolo et al. 1987; Manni et al. 1993) and is connected to the atrial epithelium by vesicular oviduct. Ovulation of eggs occurs inside the zooids at the onset of each blastogenic cycle, in blastogenic stage A (Milkman 1967; Rodriguez et al. 2016). During ovulation, the outer follicular layer is peeled off the egg, exposing the internal follicular layer. The outer layer then forms an ephemeral corpus luteum, and the egg ruptures and moves through the vesicular oviduct. Each egg hangs on the atrial wall and the epithelium of the oviduct, and together with the atrial epithelium, a cuplike "placenta" is formed. The inner follicular layer adheres to the placenta, forming junctional spots with the oviduct epithelium and the filamentous layer that anchors the layers, ensuring the attachment of the embryo to the parent. The corpus luteum is resorbed before gastrulation (Zaniolo et al. 1987) and then the outer follicular layer disintegrates and disappears (Mukai 1977). Oocytes, primordial germ cells (PGCs) and germ cells circulate freely in the blood system, temporarily occupy niches within colonial modules (zooids and buds) and move between generations of modules (Sabbadin and Zaniolo 1979; Magor et al. 1999; Voskoboynik et al. 2008). During their journey, PGCs present stemness genes such as BS-Vasa, BS-DDX1, $\gamma$-H2AX, BS-cadherin, phosphor-Smad1/5/8 and more (Rosner et al. 2013).

A testis (Figure 21.4) is a multilobe structure made of branched tubes ending in swollen follicles that host the undifferentiated germ stem cells and all daughter cells through spermatogenesis and where the most mature cells are located in the middle of the follicles and the least developed cells in the periphery (Burighel and Cloney 1997). Spermatogenesis initiates in blastogenic stage A1. During testis maturation (blastogenic stage B1), sperm is released from the atrial siphon, aided by the hydraulic force to be swept away far from the colony (Milkman 1967; Burighel and Cloney 1997), so along blastogenic stage C1, most of the sperm is already released (Rodriguez et al. 2016). Several associated gene expressions (e.g. tetraspanin-8, testis-specific serine/threonine protein kinase-1 and vitellogenin-1) typify spermatogenesis as Otoancorin, a marker for developing testes (Rodriguez et al. 2014).
The cleavage of the ascidian embryo is holoblastic and bilateral, and the gastrulation occurs by epiboly and invagination, while the large archenteron (where the notochord is formed) eliminates the blastocoel. The archenteron proliferates laterally, growing into a solid band of mesodermal cells in each side of the body, and, unlike other deuterostomes, in ascidians, the mesodermal bands do not arise by enterocoely and do not develop coelomic cavities. The differentiation of the ectoderm occurs along the mid-dorsal line into a neural tube where the ectoderm sinks inward and rolls upward, forming the neural tube. The embryo is developed to a lecithotropic, non-feeding larva (Figure 21.3a) that hatches and swims throughout the oral siphon into the outer world (Berrill 1950; Rodriguez et al. 2016), according to Mukai (1977).

The tadpole larva is divided into a visceral trunk and locomotory tail (Figure 21.3a). The trunk contains cerebral vesicle and viscera. The digestive system that exists in the larva does not function yet and will remain in the newly developed oozooid following metamorphosis (Figure $21.3 \mathrm{~b}$ ). The tail is propulsive and contains musculature, the notochord (a hollow tube that contains extracellular fluid), dorsal neural tube and an endodermal rudiment, while the dorsal and the ventral fins on the tail are folds of the larval tunic. The cerebral vesicle, which is located in the dilated anterior end of the neural tube, includes the ocellus and statocyst (Ruppert et al. 2004). The life-span of the swimming larva is short (less than one hour), following which the larva attaches to a substrate, aided by three anterior adhesive papillae and metamorphoses. The tail is retracted and absorbed, resulting in the loss of the notochord, dorsal hollow nerve cord, the musculature and the endodermal rudiment. The area between the adhesive papillae goes through a massive growth, resulting in a rotation of the body by $90^{\circ}$, positioning the siphons upward (opposite to the substrate). Then the atrium expands, enclosing the anus and the pharynx. The oozooid gives rise to the first zooid (Figure 21.3c), which, following several blastogenic cycles, will form a colonial entity (Figures 21.1a, 21.3d) (Ruppert et al. 2004).

\subsection{ANATOMY}

Botryllus schlosseri, like all other ascidians in the subphylum Tunicata, lacks the typical chordate features while possessing in the larval stage the essential chordate traits of a hollow dorsal nerve cord, a notochord, pharyngeal pouches and a tail (Berrill 1935; Ruppert et al. 2004).

Botryllus schlosseri colonies vary in color phenotypes, ranging from yellow, orange and brown to blue, green, gray and more. The intensity of colors and variation in coloration may be affected by age and environmental state of the colony (Milkman 1967; Lauzon et al. 2000), but the animal's basic color patterns are based on genetics (Sabbadin 1977). The sizes of Botryllus colonies are variable and can range from a few millimeters to several centimeters, depending on the number of zooids in a colony, from few to thousands (compare Figure 21.1a to Figure 21.3d) (Chadwick-Furman 
and Weissman 1995). From the anatomy point of view, a Botryllus schlosseri colony can be defined according to three levels of body organizations: the entire colony/genet level, the level of the system/ramet and the level of the modules (Rinkevich 2017). The following text considers the Botryllus anatomy at each level of organization.

The colonial mass (the genet, as well as each separated ramet) of Botryllus schlosseri is composed of a different number of modules (the zooids; in diverse developmental stages), which are embedded in the tunic and are connected to each other through a ramified blood system. The tunic is a gelatinous-like, fibrous, transparent extra-cellular matrix (Figure 21.1a, Figure 21.3) (Zaniolo 1981). It contains mainly carbohydrates and also proteins and motile cells (Smith and Dehnel 1971; Richmond 1991; Ruppert et al. 2004). A cellulose-like polymer named tunicin is abundant in the tunic. Tunicates are the only known animals that have a unique ability to produce cellulose-like materials using a cellulosesynthase (Nakashima et al. 2004, 2008; Inoue et al. 2019). The tunic envelops the zooids with a thin, dense cuticle layer that covers the entire tunic (Zaniolo 1981). Three types of test cells are found in the tunic. The first and most abundant cell type is the vacuolated motile cells, defined by filopodia that are homogeneously distributed in the tunic (Izzard 1974; Zaniolo 1981; Hirose et al. 1991; Hirose 2009). The other two test cell types are fusiform cells that are usually found adjacent to vessel walls and fibrocytes that have pseudopodia and are spread in the tunic (Zaniolo 1981; Hirose et al. 1991; Hirose 2009). In addition, diverse types of blood cells infiltrate and found in the tunic (Ruppert et al. 2004; Hirose 2009). The tunic and the test cells form together a complex connective-like tissue (Nakashima et al. 2008).

A ramified vasculature system is embedded in the tunic (Berrill 1950; Ruppert et al. 2004) and connects between all zooids. Each blood vessel in the network is made of an epithelium that connects to the zooids. The blood system of the zooids is open and contains lacunae across organs (Milkman 1967; Gasparini et al. 2007). The tunic vessels are uniquely lined by epidermis and epidermal basal lamina (Ruppert et al. 2004). The vessels are terminated in ampullae, numerous swollen thickening endings, sausage-like structures (Figure 21.4), located in the external boundaries of the tunic that help the colony to attach to or glide on the substrate (Katow and Watanabe 1978). The blood flows due to the contraction of both the zooids' hearts and the ampullae (Milkman 1967). The ampullae are the organs for primary physical contact sites in allorecognition and are the areas for self/non-self recognition between colonies (more details in section "Functional Approaches: Tools for Molecular and Cellular Analyses") (Katow and Watanabe 1980; Rinkevich and Weissman 1987a, 1987b).

The zooids are embedded within the tunic, in accordance with the Botryllus-specific pattern formation, as circular, star-like structures, each termed a system, ergo the epithet "star-ascidian" for Botryllus (a colony with two systems is shown in Figure 21.3d). Each system contains up to 10-12 zooids, and the numbers of systems/zooids in colonies vary, depending on free substrate space, environment conditions and colony vitality (Chadwick-Furman and Weissman 1995; Lauzon et al. 2000). The atrial siphons of the grouped zooids open into a common atrial chamber.

It is customary to separate (sub-clone) the colony into systems using a simple surgical procedure. When the separation is carried out properly, the separated systems, termed ramets, recover rapidly. Sub-cloning is a common procedure carried out in laboratories due to its experimental advantage in receiving a number of genetic-identical repeats (subcloning methodologies in Rinkevich and Weissman 1987a; Rinkevich 1995).

The zooids in Botryllus are divided into three groups according to their developmental stages, the zooids, the primary buds and the secondary buds (Figure 21.4; more on module development in the life cycle section). Here we will reveal the anatomy of the mature modules, since the buds are going through diverse stages of organogenesis. In a typical zooid, the soma is delineated by the body wall, the mantle, formed by the epidermis that contains connective tissue, blood vessels/lacunae and muscle strands. The zooid is oval, over 1 millimeter in length, and contains two openings: the oral (branchial or buccal) siphon, which is the mouth and is also used as the sperm/larvae doorway (Berrill 1950; Rodriguez et al. 2016), and the atrial siphon, which is an excretion site. The oral siphon is adorned with eight tentacles (four long and four short), leading to a pharynx, which is the branchial sac (Berrill 1950). Tunicates are filter-feeders, a process executed by the branchial sac (Figure 21.4), attaining their food from the seawater by intake of water through periodic contraction of the body wall. Food is filtered through the branchial sac by dedicated ciliatic cells arranged in slits named stigmata. This organ also participates in respiration process. Planktonic food is captured by the mucus in the branchial sac and then collected and transported via the cilia to the digestive system located in the visceral cavity, started from the pharynx, to the esophagus, the stomach, the U-shaped gut and last the atrium and outside the body through the atrial siphon (Berrill 1950). Botryllus, like other tunicates, lacks conventional nephridia. Instead, ammonia is released by diffusion, while other by-products such as uric acid and calcium oxalate are stored in specialized cells named nephrocytes that accumulate in various tissues (Ruppert et al. 2004)

The nervous system is composed of a cerebral ganglion and a neural (pyloric) gland. The cerebral ganglion is a rounded hollow "brain" located in a connective tissue, where the stemming nerves connect to the branchial siphon and to musculature (Ruppert et al. 2004). The pyloric gland is a hollow blind-sac stemming from the basal region of the stomach, branching over the wall of the intestine and ending in ampullae, and is involved in the evaluation of environmental signals (Burighel et al. 1998). A monoclonal antibody that is specific to the cells of the pyloric gland has been developed (Lapidot et al. 2003), a unique tool in research. 


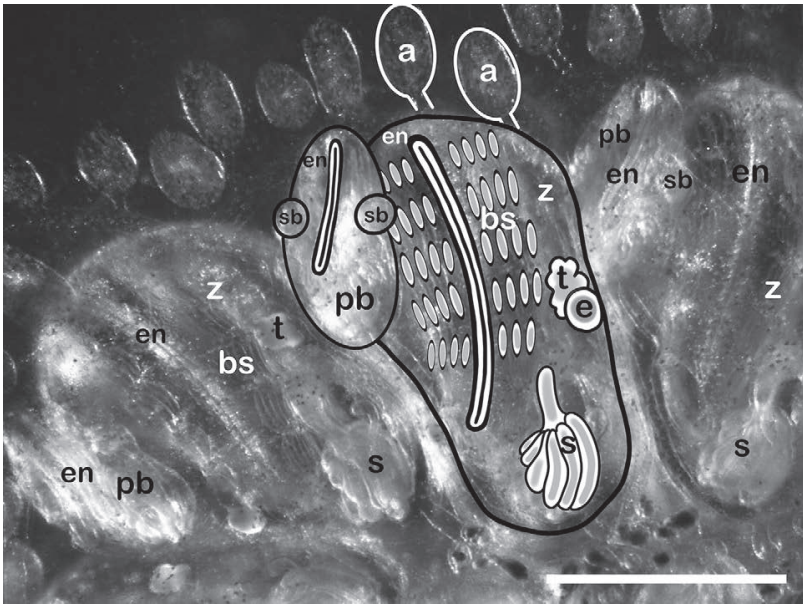

FIGURE 21.4 A close-up back-side photo of a colony growing on a glass slide, superimposed (in the center) with illustration describing the anatomy of the three generations of colonial modules. The zooid (z) is the mature module, and to the left of it is a primary bud (pb) marked with two secondary buds (sb) that appear as small round protrusions. The endostyle (en) is illustrated as elongated organ and is clearly seen in the zooid and in the primary bud. The branchial sac (bs) is composed of the endostyle and the stigmata, represented here by numerous oval-like thin structures. Zooids may contain testes (t) and an egg (e). "s" refers to the stomach. Blood vessel endings, the ampullae (a), are also marked as swollen structures at the periphery of the colony. Scale bar $=0.5 \mathrm{~mm}$.

The heart is a long, tube-shaped structure made of a simple epithelium and striated muscle. The blood flows through the heart thanks to peristaltic movement waves. The zooids' heartbeats are synchronized for the rate and direction of flow. The hearts beat together so that the blood flows in the same direction for a few seconds and then stop and continue to beat in the opposite direction.

In the dorsal part of the zooid, a long, tube-like organ named the endostyle (Figure 21.4) is composed of eight zones, even and odd, where the odd zones have cilia and are in charge of mucus propelling, while the even zones manifest secretion (Burighel and Cloney 1997). The endostyle is a vertebrate thyroid homologue that further synthesizes and secretes thyroid hormones used for iodine metabolism (Ogasawara et al. 1999). In addition, it serves as a transient niche for hematopoietic stem cells (Voskoboynik et al. 2008) and is highly functional in feeding, secreting a mucus net aiding the branchial sac to capture food particles (Holley 1986; Burighel and Cloney 1997).

\subsection{GENOMIC DATA}

Using a novel high-throughput method for eukaryotic genome sequencing, a draft genome of Botryllus schlosseri from Monterey, California, possessing 27,000 estimated genes and 38,730 putative protein-coding loci, was published in 2013 (Voskoboynik et al. 2013a). Former genomic analyses using flow cytometry elucidated a genome size of $725 \mathrm{Mb}$ (De Tomaso et al. 1998), based on 16 haploid chromosomes (according to Colombera 1963) or 13 (according to Voskoboynik et al. 2013a). About $65 \%$ of the $B$. schlosseri draft genome is composed of repeating segments, summing up to 6,601 repetitive families, each with three copies or more. A particular group of 1,400 large interspersed repeat gene families that are over $1 \mathrm{~kb}$ in length are located at dispersed genomic regions, with $>10 \%$ that each possess $>100$ copies, and are found in several chromosomes. The average size of a gene is $3.6 \mathrm{kbp}$, and the average size of an exon is $170 \mathrm{bp}$. In order to estimate the protein-encoding genes, transcriptome sequence data were constructed from 19 B. schlosseri colonies. The transcriptome was compared to the list of the putative proteins, revealing at least $30 \%$ matches that support the sequenced genome validity (Voskoboynik et al. 2013a). Further, to evaluate the Botryllus phylogenetic relationships with other taxa, Voskoboynik et al. (2013a) compared 521 nuclear gene sequences $(40,798$ aligned amino acids) with homologous sequences from 14 other model species, including six vertebrates, a tunicate, a cephalochordate, an echinoderm, an insect, two cnidarians, a sponge and a choanoflagellate. Meta-analysis supported the prevailing notion that Botryllus, as a tunicate, belongs to the phylum Chordata. The predicted proteomics of Botryllus, which was compared with vertebrate proteomics, revealed high homologies: $77 \%$ with human, $85 \%$ with chicken and $86 \%$ with frog, suggesting a common ancestor. Also, Botryllus is the only protochordate that carries genes related to pregnancy-specific-glycoproteins (PSGs) (Voskoboynik et al. 2013a). The browser of the Botryllus genome is found at either of these links: http://botryllus.stanford.edu/botryllusgenome/ or http://hegemon.ucsd.edu/bot/.

Mitochondrial genome sequencing (Voskoboynik et al. 2013a) revealed 14,928-bp-long mtDNA that includes 24 tRNAs, 2 rRNAs and 13 proteins. This composition of proteins and nuclear acids is typical to tunicate mitochondrial genes. The sequences of the 13 putative proteins in the Botryllus mtDNA were further subjected to phylogenetic analyses and were compared to 66 organisms, including tunicates, vertebrates, cephalochordates, xenoturbellides, hemichordates, echinodermates and two outgroups (arthropods and mollusks), suggesting, as with the nuclear gene phylogenetics, a common ancestor with vertebrates. Results further demonstrated high substitution rates of nucleotides in tunicates and that the stolidobrancian tunicates (including Botryllus) create a monophyletic group (Voskoboynik et al. 2013a).

Gao et al. (2018) developed a large resource of Botryllus single-nucleotide polymorphism (SNP) using restriction siteassociated DNA (RAD) tag sequencing, revealing 14,119 SNPs that are available for use. The SNPs served as markers to evaluate population genetic characteristics in Botryllus.

Studying Botryllus within diverse areas of interest such as astogeny of colonial organisms (blastogenesis; Manni et al. 2007; Ben-Hamo et al. 2018; Manni et al. 2019), regeneration (including whole-body regeneration; Rinkevich and Weissman 1990; Voskoboynik et al. 2007; Rinkevich and Rinkevich 2013; Rosner et al. 2019), allorecognition and population genetics gained informative genomic data, 
partially unveiling the cryptic biology underlying these phenomena. The following paragraphs summarize the central publications on the genomic data.

Blastogenesis has been well characterized in Botryllus both anatomically and ontogenically (Manni et al. 2019; Manni et al. 2014; Sabbadin et al. 1975; Izzard 1973; Berrill 1941a, 1941b). Recent years have yielded novel insights on the molecular processes underlying blastogenesis (Franchi et al. 2017; Campagna et al. 2016; Ricci et al. 2016a; Rodriguez et al. 2014; Rinkevich et al. 2013; Rosner et al. 2014, 2019; Qarri et al. 2020). Transcriptomes of three major stages along the Botryllus blastogenic cycle (midcycle, the pre-takeover and the takeover phases; Campagna et al. 2016; available at http://botryllus.cribi.unipd.it) have revealed 11,337 new genes, of which 581 transcripts were determined with complete open reading frames. Many sequences emerged as genes involved in apoptosis activation, de-activation and regulation (Campagna et al. 2016). Analyzing the differential expression for fertile vs. infertile B. schlosseri colonies, Rodriguez et al. (2014) revealed a set of genes that are differentially expressed in every blastogenesis stage analyzed. The highest numbers of differentially expressed genes were found in early stages, many of which are homologous to vertebrates. These genes have conserved roles in organism fertility (Rodriguez et al. 2014).

Ricci et al. (2016b) constructed transcriptomics libraries from epithelial tissues of developing buds and from non-developing buds and revealed differentially expressed gene expressions in the developing bud epithelial tissues that are associated with regeneration and stem cell functions and homologous to genes in other model organisms. Further sets of unknown genes were elucidated, indicating possible specific genes and functions associated with budding in B. schlosseri colonies (Ricci et al. 2016b), while in other cases, such as in response to reactive oxygen species (ROS) that emerge during the takeover stage (Cima et al. 1996; Voskoboynik et al. 2004), five transcripts for antioxidant defense enzymes [SOD (superoxide dismutase), GCLM (glutamyl-cysteine ligase modulatory subunit), GS (glutathione synthase), GPx3 and GPx5 (two glutathione peroxidases)] were identified (Franchi et al. 2017).

Allorecognition in botryllid ascidians is manifested when two or more genotypes come into physical contact with each other, resulting in either fusion (chimera formation) or rejection (see more in "Functional Approaches: Tools for Molecular and Cellular Analyses"). To assess the repertoire of differentially expressed genes during rejection, Oren et al. (2007) constructed expressed sequence tag (EST) libraries where allogeneic challenged colonies were compared to naïve counterparts and revealed dozens of specifically expressed genes homologous to genes involved in diverse immunological processes. The list includes stress proteins, pattern recognition receptors, complement proteins, proteases and protease inhibitors, cell adhesion and coagulation proteins, cytokine-related proteins, programmed cell death and proteasome-related proteins (Oren et al. 2007). Then Oren et al. (2010) elucidated transcriptional differences between the genotypes involved in the allogeneic rejection processes, the partner that displays the points of rejection (PORs; rejected partner) and the rejecting partner "causing" the PORs. Microarray and complementary qPCR assays revealed two distinct transcriptional landscapes for "rejected" vs. "rejecting" colonies in the same allogeneic assay. In the "rejected" colonies, $87 \%$ of the ESTs were downregulated as compared to the "rejecting" partner showing only minor changes $(0.7 \%)$ in the allogeneic assay. In the "rejected" transcriptome, three functional groups were downregulated substantially: protein biosynthesis, cell structure and motility and immune-related genes, overall depicting the inhibition of response components rather than enhancement of immunologic responses (Oren et al. 2010).

Studies were further engaged with the Botryllus regeneration abilities and the roles of stem cells in this process (Braden et al. 2014; including whole-body regeneration; Rinkevich and Weissman 1990; Voskoboynik et al. 2007; Rinkevich and Rinkevich 2013; Rosner et al. 2019). According to these studies, stem cells circulate the blood system of the colonies and are confined to dedicated stem cell niches as the niches adjacent to the endostyle. Stem cells play a pivotal role in budding de novo of new generations of modules and in regeneration according to their genomic signatures. Three presumed stem cell populations were described in Botryllus (CP25, CP33 and CP34), and their expressed genes overlap with those of the mouse hematopoietic stem cells (Rosental et al. 2018).

\subsection{FUNCTIONAL APPROACHES: TOOLS FOR MOLECULAR AND CELLULAR ANALYSES}

Colonial tunicates such as Botryllus schlosseri express unique biological phenomena and are valuable models for variety of research fields, yielding novel discoveries and functional tools in the research. We detail an overview of three main tools that can be applied for diverse studies.

\subsubsection{A Model for Chimerism}

The first research tool is the use of Botryllus schlosseri as an accessible model system for allorecognition, primarily for chimera formation. Chimerism is the biological state where an organism is composed of cells originating from two genetically distinct conspecifics and is based on the capacity for morphological fusions between these organisms (Figure 21.3e). Artificial chimerism (performed in research institutions) is being achieved in model organisms such as frogs (Volpe and Earley 1970), rats (Fang 1971) and mice (Eichwald et al. 1959), established by uniting allogeneic cells during early embryonic stages or via surgical interventions in adults. These systems have proved an indispensible tool for a variety of research fields, such as hematology (Abkowitz et al. 2003), immunology (Liu et al. 2007), aging (Conboy et al. 2013) and more. Although parabiosis is an important system for studies, two main challenges keep it from being used on a wide scale in biology. First, growing public concern in recent 
years delegitimizes the use of adult parabionts in experimental settings, and second, the traumatic protocols cause enormous stress that may influence the results of the studies. Botryllus chimerism may alleviate these challenges.

Botryllid ascidians possess a unique type of immunity (allorecognition system) that may reveal the evolutionary routes for vertebrate immune systems (Magor et al. 1999; Weissman et al. 1990; Cooper et al. 1992; Rinkevich 2004, 2005a), as well as chimerism, revealing evolutionary and ecological aspects for this phenomenon (Rinkevich 2005b). Interest in B. schlosseri immunity has centered on allogeneic recognition and its consequences, as pairs of colonies that meet naturally (or in the laboratory) either anastomose contacting ampullae to form a vascular parabiont (Figure 21.3e) or develop cytotoxic lesions in the contact zones (termed points of rejection; Sabbadin and Astorri 1988; Teneda et al. 1985; Rinkevich and Weissman 1987a, 1987b, 1987c, 1991; Weissman et al. 1990; Rinkevich 1992, 1996, 1999a). In many cases, pairs of colonies that fused or rejected each other retreat, growing from their points/areas of contact (Rinkevich and Weissman 1988). B. schlosseri chimeras were widely recorded in the field (Ben-Shlomo et al. 2001), most likely the outcome of co-settlement aggregates of histocompatible kin colonies (Grosberg and Quinn 1986). Once colonies fuse, a second allorecognition phenomenon begins which leads to the morphological elimination (resorption) of one partner in the chimera (Rinkevich and Weissman 1987a, 1987b, 1987c, 1989; 1992a, 1992b; Sabbadin and Astorri 1988), termed allogeneic or chimeric resorption (Rinkevich 2005a) and based on a highly complex and polymorphic organization of histocompatibility alleles, revealing a clear hierarchy in the resorption phenomenon (Rinkevich 1993; Rinkevich et al. 1993). Yet a mild stress may change resorption directionality in B. schlosseri chimeras by expressing a non-genetic type of apoptotic pathways (Rinkevich et al. 1994).

One of the most interesting outcomes of chimerism in B. schlosseri are the phenomena of somatic/germ cell parasitism (Sabbadin and Zaniolo 1979; Pancer et al. 1995; Stoner and Weissman 1996; Magor et al. 1999; Stoner et al. 1999; Rinkevich and Yankelevich 2004; Simon-Blecher et al. 2004). Somatic and germ cell parasitism in chimeric B. schlosseri colonies are recognized when the soma and/ or the gonads do not reflect equal contributions by the partners involved and are further recorded in "forced chimeras" established between allogeneic noncompatible partners (Rinkevich and Weissman 1998; Simon-Blecher et al. 2004). Germ cell parasitism in this system is fixed, reproducible, reveals hierarchical arrangements and, above all, is sexually inherited (Stoner et al. 1999; Rinkevich and Yankelevich 2004). In contrast, somatic cell parasitism, while reproducible and hierarchical, has not been characterized by the trait of sexual inheritance through a pedigree (Stoner et al. 1999). It may thus be concluded that somatic and germ cell parasitism are unlinked phenomena (Stoner et al. 1999; Magor et al. 1999; Rinkevich and Yankelevich 2004) and that for both types of cell parasitism, the chimeric entity enables foreign somatic and germ stem cells to hitchhike within the "winner" genotypes without being visible to natural selection forces that act on the winner genotypes (Rinkevich 2002a, 2002b, 2004a, 2004b, 2011a), part of the proposed "costs" for chimerism (Rinkevich 2002b, 2005b, 2011a). Yet several studies that evaluated "costs" and "benefits" predictions for chimerism in B. schlosseri revealed two major benefits, the shifts of the somatic constituents within chimeras in accordance with changes in environmental conditions and the expression of the heterosis phenomenon in chimeras, occurred via scrutinizing against genotypes that are less adapted to adverse environmental conditions (Rinkevich 1993, 2005b; Rinkevich et al. 1993; Rinkevich and Yankelevich 2004). This attests to the indispensable tool of B. schlosseri in the study on chimerism, allorecognition (see also Oren et al. 2010, 2013) and the evolution of immunity.

\subsubsection{Accessible Regeneration/Aging Stem Cell-Mediated System}

Scientific efforts that have been made over the years to study the biology of stem cells in vertebrates and have led to important understanding in the roles of stem cells in regeneration and aging (Conboy et al. 2015; Singer 2016; Bacakova et al. 2018; Busque et al. 2018; Keyes and Fuchs 2018). Since stem cells play a crucial role in regenerative abilities and aging of multi-cellular organisms, some consider these two phenomena opposite correlated and bounded by stem cell fitness (Conboy et al. 2015; Singer 2016; Keyes and Fuchs 2018). In comparison to the vast knowledge gained on stem cells in vertebrates, little is known on the function of stem cells in invertebrates (Vogt 2012; Ballarin et al. 2018). As opposed to vertebrates, invertebrates have impressive abilities to regenerate their bodies. Some hypotheses suggest reasoning for the gradual loss of regenerative abilities from invertebrates to vertebrates (Rinkevich and Rinkevich 2013; Luisetto et al. 2020). Botryllus schlosseri is an optimal model for studies of adult stem cells, regeneration and aging (Rosner et al. 2006, 2007, 2013, 2019; Voskoboynik et al. 2007, 2008, 2009; Rosner and Rinkevich 2007; Rinkevich 2011b; Rinkevich et al. 2013; Munday et al. 2015; Voskoboynik and Weissman 2015; Rinkevich 2017; Ben-Hamo et al. 2018; Qarri et al. 2020). Asexual budding cycles (blastogenesis) include de novo whole body regeneration every week throughout the life of colonies (more info in life-cycle section). In addition to the weekly death and growth cycles (Rinkevich 2019), Botryllus is able to perform vascular budding of new modules after amputating all existing modules except tunic and blood vessels (Sabbadin et al. 1975; Voskoboynik et al. 2007) and following major stress phenomena, including irradiation (Rinkevich and Weissman 1990; Voskoboynik et al. 2002, 2004; Qarri et al. 2020). Stem cells were further defined as units of selection of the species (Laird et al. 2005a; Rinkevich et al. 2009; Weissman 2015). Thus, Botryllus is a unique, omnipotent model organism for studies of regeneration, aging and stem cell biology. 


\subsubsection{Accessible IN Vitro Invertebrate Cultures}

In vitro approaches in research have advanced scientific disciplines, yet, in spite of significant efforts invested, they have not been successful in obtaining stable in vitro tissue cultures from any marine invertebrate, including from Botryllus (Rinkevich 1999b, 2005c, 2011b; Grasela et al. 2012). In spite of these failures, several primary cultures were developed successfully from embryos and larvae (Rinkevich and Rabinowitz 1994) and epithelial cell cultures from palleal buds (Rinkevich and Rabinowitz 1997; Rabinowitz and Rinkevich 2003, 2004, 2011; Rabinowitz et al. 2009). These in vitro approaches revealed that abrogating the in vivo colonial homeostasis resulted in extended life span and developmental features not recorded along blastogenesis. For example, extirpated buds (in vitro organ cultures) at blastogenesis stages B to D attached to the bottoms developed novel spheres (up to $1 \mathrm{~mm}$ diameter), and then they developed epithelial monolayers on substrates for the next ten days, about a fivefold increase in life expectancy under in vitro conditions. Further, instead of the apoptotic death of cells under normal blastogenesis (Lauzon et al. 2002), the in vitro death of epithelial monolayers was necrotic (Rabinowitz and Rinkevich 2004). Results revealed the unexpected regenerative power of isolated blastogenic stage D zooids (at the takeover phase process) under in vitro conditions that developed almost three times more epithelial monolayers than blastogenetic stages B and $\mathrm{C}$ buds, with a higher order of magnitude in monolayerto-sphere ratio (Rabinowitz and Rinkevich 2004, 2011), and the vast majority of these stage D buds developed epithelial monolayers directly, without forming spheres. Generally speaking, Rabinowitz et al. (2009) showed enhanced expressions of actin, PL10, P-MEK, MAP-kinase, Piwi and cadherin in extirpated buds and monolayers, exhibiting de novo emergent stemness signatures.

\subsection{CHALLENGING QUESTIONS BOTH IN ACADEMIC AND APPLIED RESEARCH}

Botryllus schlosseri presents unique biological phenomena which are highly valuable to several fields in biology (Rinkevich 2002a; Manni et al. 2007; Voskoboynik and Weissman 2015; Manni et al. 2019). Yet studies on Botryllus are engaged with challenges that have not yet been solved. In the following, we will overview three major research challenges.

\subsubsection{Breeding in the Laboratory}

In spite of the growing scientific interest in using Botryllus schlosseri as a model organism in a wide range of scientific disciplines, only three laboratories worldwide hold colonies in captivity (in California, at Hopkins Marine Station, Stanford University; in Italy, at the University of Padova; and in Israel, at the National Institute of Oceanography, Haifa). In some other laboratories, such as in Japan (Shimoda Marine Station), some B. schlosseri colonies were held in the past. All these sites commonly have access to seawater facilities, while the methodologies of animal maintenance differ (e.g. in Israel, Rinkevich and Shapira 1998; in California, Boyd et al. 1986; in Italy, Brunetti et al. 1984). One of the challenges holding back development of brood stocks for research is therefore the development of methodologies and facilities for inland maintenance of the animals. For example, the use of artificial seawater has not yet been reported in the literature, and the current only way to hold stocks of breeding, healthy and fertile Botryllus colonies over time is the use of fresh seawater, in most cases using running seawater systems.

\subsubsection{Lack of Sufficient Molecular Research ToOls}

For esoteric model organisms such as Botryllus schlosseri, one major obstacle is the lower efforts dedicated to developing adequate molecular tools by research laboratories and commercial companies, in contradiction to the investment in molecular tools for "popular" model organisms. Even basic tools, such as specific antibodies for Botryllus, cannot be commercially supplied and should be prepared in the lab, a time- and moneyconsuming process. Another struggle is the current failure to produce transgenic Botryllus or apply CRISPR gene editing on this species. These burdens slow the progress of research on Botryllus and can be eased if more laboratories will join the community of Botryllus schlosseri researchers.

\subsubsection{Lack of Inbred Strains/Lines}

In popular models, a variety of inbred lines and strains of animals are available, including strains that are being used as models for specific diseases and deficiencies. At the moment, there is no single inbred strain or line of Botryllus, and the diverse laboratories obtain the animals from their geographic marine locations, revealing high variations between animals. The lack of common strains for research may harm the ability to compare between studies due to variations between and within Botryllus ecotypes that stem from sampling different geographic locations and/or different Botryllus clades.

\section{BIBLIOGRAPHY}

Abkowitz, J.L., Abigail E.R., Sujata K., Michael W.L., and Jing, C. 2003. Mobilization of hematopoietic stem cells during homeostasis and after cytokine exposure. Blood. 102:1249-1253.

Bacakova, L., Zarubova, J., Travnickova, M., Musilkova, J., Pajorova, J., Slepicka, P., Kasalkova, N.S., Svorcik, V., Kolska, Z., Motarjemi, H., and Molitor, M. 2018. Stem cells: Their source, potency and use in regenerative therapies with focus on adipose-derived stem cells: A review. Biotechnology Advances. 36:1111-1126.

Ballarin, L., Burighel, P., and Cima, F. 2008. A tale of death and life: Natural apoptosis in the colonial ascidian Botryllus schlosseri 
(Urochordata, Ascidiacea). Current Pharmaceutical Design. 14:138-147.

Ballarin, L., and Cima, F. 2005. Cytochemical properties of Botryllus schlosseri haemocytes: Indications for morpho-functional characterisation. European Journal of Histochemistry. 49:255-264.

Ballarin, L., Rinkevich, B., Bartscherer, K., Burzynski, A., Cambier, S., Cammarata, M., Domart-Coulon, I., Drobne, D., Encinas, J., Frank, U., Geneviere, A.M., Hobmayer, B., Löhelaid, H., Lyons, D., Martinez, P., Oliveri, P., Peric, L., Piraino, S., Ramšak, A., Rakers, S., Rentzsch, F., Rosner, A., Silva, T.H. da, Somorjai, I., Suleiman, S., and Coelho, A.V. 2018. Maristem: Stem cells of marine/aquatic invertebrates: From basic research to innovative applications. Sustainability. 10:1-21.

Ballarin, L., Schiavon, F., and Manni, L. 2010. Natural apoptosis during the blastogenetic cycle of the colonial ascidian Botryllus schlosseri: A morphological analysis. Zoological Science. 27: 96-102.

Bancroft, F.W. 1903. Variation and fusion of colonies in compound ascidians. Proceedings of the California Academy of Sciences, 3rd Series. 3:137-186.

Ben-Hamo, O., Rosner, A., Rabinowitz, C., Oren, M., and Rinkevich, B. 2018. Coupling astogenic aging in the colonial tunicate Botryllus schlosseri with the stress protein mortalin. Developmental Biology. 433:33-46.

Ben-Shlomo, R., Douek, J., and Rinkevich, B. 2001. Heterozygote deficiency and chimerism in remote populations of a colonial ascidian from New Zealand. Marine Ecology Progress Series. 209:109-117.

Ben-Shlomo, R., Paz, G., and Rinkevich, B. 2006. Postglacialperiod and recent invasions shape the population genetics of botryllid ascidians along European Atlantic coasts. Ecosystems. 9:1118-1127.

Ben-Shlomo, R., Reem, E., Douek, J., and Rinkevich, B. 2010. Population genetics of the invasive ascidian Botryllus schlosseri from South American coasts. Marine Ecology Progress Series. 412:85-92.

Bernier, R.Y., Locke, A., and Hanson, J.M. 2009. Lobsters and crabs as potential vectors for tunicate dispersal in the southern Gulf of St. Lawrence, Canada. Aquatic Invasions. 4:105-110.

Berrill, N.J. 1935. VIII: Studies in tunicate development, Part III: Differential retardation and acceleration. Philosophical Transactions of the Royal Society B: Biological Sciences. 225:255-326.

Berrill, N.J. 1941a. The development of the bud in Botryllus. The Biological Bulletin. 80:169-184.

Berrill, N.J. 1941b. Size and morphogenesis in the bud of Botryllus. The Biological Bulletin. 80:185-193.

Berrill, N.J. 1950. The Tunicata with an Account of the British Species. Ray Society, London, UK. 3-56.

Berrill, N.J. 1951. Regeneration and budding in tunicates. Biological Reviews. 26:456-475.

Bock, D.G., Macisaac, H.J., and Cristescu, M.E. 2012. Multilocus genetic analyses differentiate between widespread and spatially restricted cryptic species in a model ascidian. Proceedings of the Royal Society B: Biological Sciences. 279:2377-2385.

Boorman, C.J., and Shimeld, S.M. 2002. The evolution of left-right asymmetry in chordates. BioEssays. 24:1004-1011.

Boyd, H.C., Brown, S.K., Harp, J.A., and Weissman, I.L. 1986. Growth and sexual maturation of laboratory-cultured Monterey Botryllus schlosseri. Biological Bulletin. 170:91-109.
Braden, B.P., Taketa, D.A., Pierce, J.D., Kassmer, S., Lewis, D.D., and De Tomaso, A.W. 2014. Vascular regeneration in a basal chordate is due to the presence of immobile, bi-functional cells. PLoS One. 9:e95460.

Bruguière, J.G. 1792. Encyclopédie méthodique. Histoire naturelle des vers. Tome Premier. Panckoucke, Paris. 1-757.

Brunetti, R., Marin, M.G., and Bressan, M. 1984. Combined effects of temperature and salinity on sexual reproduction and colonial growth of Botryllus schlosseri (Tunicata). Bollettino di Zoologia. 51:405-411.

Burighel, P., and Cloney, R.A. 1997. Urochordata: Ascidiacea. In Microscopic Anatomy of Invertebrates, eds. Harrison, F.W., and Ruppert, E.E. 221-347. Wiley-Liss Inc, New York.

Burighel, P., Lane, N.J., Zaniolo, G., and Manni, L. 1998. Neurogenic role of the neural gland in the development of the ascidian, Botryllus schlosseri (tunicata, urochordata). Journal of Comparative Neurology. 394:230-241.

Busque, L., Buscarlet, M., Mollica, L., and Levine, R.L. 2018. Concise review: Age-related clonal hematopoiesis: Stem cells tempting the devil. Stem Cells. 36:1287-1294.

Campagna, D., Gasparini, F., Franchi, N., Vitulo, N., Ballin, F., Manni, L., Valle, G., and Ballarin, L. 2016. Transcriptome dynamics in the asexual cycle of the chordate Botryllus schlosseri. BMC Genomics. 17:275.

Carlton J.T. 2005. Setting ascidian invasions on the global stage. In Proc Int Invasive Sea Squirt Conf. 21-22. Woods Hole Oceanographic Institution, Woods Hole, MA.

Carman, M.R., Lindell, S., Green-Beach, E., and Starczak, V.R. 2016. Treatments to eradicate invasive tunicate fouling from blue mussel seed and aquaculture socks. Management of Biological Invasions. 7:101-110.

Castilla, J.C., Uribe, M., Bahamonde, N., Clarke, M., DesqueyrouxFaúndez, R., Kong, I., Moyano, H., Rozbaczylo, N., Santelices, B., Valdovinos, C., and Zavala, P. 2005. Down under the Southeastern Pacific: Marine non-indigenous species in Chile. Biological Invasions. 7:213-232.

Chadwick-Furman, N.E., and Weissman, I.L. 1995. Life histories and senescence of Botryllus schlosseri (chordata, ascidiacea) in Monterey Bay. Biological Bulletin. 189:36-41.

Cima, F., Ballarin, L., and Sabbadin, A. 1996. New data on phagocytes and phagocytosis in the compound ascidian Botryllus schlosseri (tunicata, ascidiacea). Italian Journal of Zoology. 63:357-364.

Cima, F., Basso, G., and Ballarin, L. 2003. Apoptosis and phosphatidylserine-mediated recognition during the takeover phase of the colonial life-cycle in the ascidian Botryllus schlosseri. Cell and Tissue Research. 312:369-376.

Cima, F., Manni, L., Basso, G., Fortunato, E., Accordi, B., Schiavon, F., and Ballarin, L. 2010. Hovering between death and life: Natural apoptosis and phagocytes in the blastogenetic cycle of the colonial ascidian Botryllus schlosseri. Developmental and Comparative Immunology. 34:272-285.

Colombera, D. 1963. Chromosomes of Botryllus schlosseri (Ascidiacea). La Ricerca scientifica. Parte 2, Rendiconti. Sezione B, Biologica. 3:443-448.

Conboy, I.M., Conboy, M.J., and Rebo, J. 2015. Systemic problems: A perspective on stem cell aging and rejuvenation. Aging. 7:754-765.

Conboy, M.J., Conboy, I.M., and Rando, T.A. 2013. Heterochronic parabiosis: Historical perspective and methodological considerations for studies of aging and longevity. Aging Cell. 12:525-530. 
Cooper, E.L., Rinkevich, B., Uhlenbruck, G., and Valembois, P. 1992. Invertebrate immunity: Another viewpoint. Scandinavian Journal of Immunology. 35:247-266.

Corey, D.M., Rosental, B., Kowarsky, M., Sinha, R., Ishizuka, K.J., Palmeri, K.J., Quake, S.R., Voskoboynik, A., and Weissman, I.L. 2016. Developmental cell death programs license cytotoxic cells to eliminate histocompatible partners. Proceedings of the National Academy of Sciences of the United States of America. 113:6520-6525.

Della Valle, A. 1881. Nuove contribuzioni alla storia naturale delle ascidie composte del Golfo di Napoli. Atti della Accademia nazionale dei Lincei (Ser. 3) 10:431-498.

De Tomaso, A.W., Saito, Y., Ishizuka, K.J., Palmeri, K.J., and Weissman, I.L. 1998. Mapping the genome of a model protochordate. i.a low resolution genetic map encompassing the fusion/histocompatibility (Fu/HC) locus of Botryllus schlosseri. Genetics. 149:277-287.

Eichwald, E.J., Lustgraaf, E.C., and Strainer, M. 1959. Genetic factors in parabiosis. Journal of the National Cancer Institute. 23:1193-1213.

Epelbaum, A., Herborg, L.M., Therriault, T.W., and Pearce, C.M. 2009. Temperature and salinity effects on growth, survival, reproduction, and potential distribution of two nonindigenous botryllid ascidians in British Columbia. Journal of Experimental Marine Biology and Ecology. 369:43-52.

Fang, C.H. 1971. Improvement of the method of rats parabiosis with aortic anastomoses. Acta Medica Okayama. 25:597-603.

Fitridge, I., Dempster, T., Guenther, J., and de Nys, R. 2012. The impact and control of biofouling in marine aquaculture: A review. Biofouling. 28:649-669.

Franchi, N., Ballin, F., and Ballarin, L. 2017. Protection from oxidative stress in immunocytes of the colonial ascidian Botryllus schlosseri: Transcript characterization and expression studies. Biological Bulletin. 232:45-57.

Ganin, M. 1870. Neue Tatsachen aus der Entwicklungsgeschichte der Ascidien. Zeitschrift für wissenschaftliche Zoologie. 20:512-518.

Gao, Y., Li, S., and Zhan, A. 2018. Genome-wide single nucleotide polymorphisms (SNPs) for a model invasive ascidian Botryllus schlosseri. Genetica. 146:227-234.

Gärtner, J. 1774. Zoophyta, quaedam minuta. In Specilegia Zoologia fasc, ed. Pallas, P.S., Lange, Berlin. 10:24-41.

Gasparini, F., Longo, F., Manni, L., Burighel, P., and Zaniolo, G. 2007. Tubular sprouting as a mode of vascular formation in a colonial ascidian (Tunicata). Developmental Dynamics. 236:719-731.

Gasparini, F., Manni, L., Cima, F., Zaniolo, G., Burighel, P., Caicci, F., Franchi, N., Schiavon, F., Rigon, F., Campagna, D., and Ballarin, L. 2014. Sexual and asexual reproduction in the colonial ascidian Botryllus schlosseri. Genesis. 16:1-16.

Giard, A.M. 1872. Recherches sur les ascidies composée ou synascidies. Archives de zoologie expérimentale et générale. 1:501-687.

Grasela, J.J., Pomponi, S.A., Rinkevich, B., and Grima, J. 2012. Efforts to develop a cultured sponge cell line: Revisiting an intractable problem. In Vitro Cellular \& Developmental Biology-Animal. 48:12-20.

Grosberg, R.K., and Quinn, J.F. 1986. The genetic control and consequences of kin recognition by the larvae of a colonial marine invertebrate. Nature. 322:456-459.

Haeckel,E. 1899. Kunstformen der Natur. Verlag des Bibliograpischen Insitutts, Leipzig und Wien.
Hamada, H., Meno, C., Watanabe, D., and Saijoh, Y. 2002. Establishment of vertebrate left-right asymmetry. Nature Reviews Genetics. 3:103-113.

Herdman, E.C. 1924. Botryllus. Vol. 26. University Press.

Hirose, E. 2009. Ascidian tunic cells: Morphology and functional diversity of free cells outside the epidermis. Invertebrate Biology. 128:83-96.

Hirose, E., Saito, Y., and Watanabe, H. 1991. Tunic cell morphology and classification in botryllid ascidians. Zoological Science. 8:951-958.

Hjort, J. 1893. Über den Entwicklungscyclus der zusammengesetzen Ascidien. Mittheilungen aus der Zoologischen Station zu Neapel. 10:584-617.

Holley, M.C. 1986. Cell shape, spatial patterns of cilia, and mucusnet construction in the ascidian endostyle. Tissue and Cell. 18:667-684.

Inoue, J., Nakashima, K., and Satoh, N. 2019. ORTHOSCOPE analysis reveals the presence of the cellulose synthase gene in all tunicate genomes but not in other animal genomest. Genes. 10:1-9.

Izzard, C.S. 1973. Development of polarity and bilateral asymmetry in the palleal bud of Botryllus schlosseri (Pallas). Journal of Morphology. 139:1-26.

Izzard, C.S. 1974. Contractile filopodia and in vivo cell movement in the tunic of the ascidian, Botryllus schlosseri. Journal of Cell Science. 15:513-535.

Karahan, A., Douek, J., Paz, G., and Rinkevich, B. 2016. Population genetics features for persistent, but transient, Botryllus schlosseri (urochordata) congregations in a central Californian marina. Molecular Phylogenetics and Evolution. 101:19-31.

Katow, H., and Watanabe, H. 1978. Fine structure and possible role of ampullae on tunic supply and attachment in a compound ascidian, Botryllus primigenus Oka. Journal of Ultrastructure Research. 64:23-34.

Katow, H., and Watanabe, H. 1980. Fine structure of fusion reaction in compound ascidian Botryllus primigenus Oka. Developmental Biology. 76:1-14.

Kayiş, Ş. 2011. Ascidian tunicate, Botryllus schlosseri (Pallas, 1766) infestation on seahorse. Bulletin of the European Association of Fish Pathologists. 31:81-84.

Keyes, B.E., and Fuchs, E. 2018. Stem cells: Aging and transcriptional fingerprints. Journal of Cell Biology. 217:79-92.

Kimura, K., Tanaka, N., Nakamura, N., Takano, S., and Ohkuma, S. 2007. Knockdown of mitochondrial heat shock protein 70 promotes progeria-like phenotypes in Caenorhabditis elegans. Journal of Biological Chemistry. 282:5910-5918.

Kott, P. 2005. Catalogue of Tunicata in Australian Waters. Australian Biological Resources Study, Canberra.

Laird, D.J., Chang, W., Weissman, I.L., and Lauzon, R.J. 2005b. Identification of a novel gene involved in asexual organogenesis in the budding ascidian Botryllus schlosseri. Developmental Dynamics. 234:997-1005.

Laird, D.J., De Tomaso, A.W., and Weissman, I.L. 2005a. Stem cells are units of natural selection in a colonial ascidian. Cell. 123:1351-1360.

Lambert, C.C., and Lambert, G. 1998. Non-indigenous ascidians in Southern California harbors and marinas. Marine Biology. 130:675-688.

Lambert, C.C., and Lambert, G. 2003. Persistence and differential distribution of nonindigenous ascidians in harbors of the 
Southern California Bight. Marine Ecology Progress Series. 259:145-161.

Lambert, G. 2001. A global overview of ascidian introductions and their possible impact on the endemic fauna. In The Biology of Ascidians, eds. Sawada, H., Yokosawa, H., and Lambert, C.C. 249-257. Springer, Tokyo.

Lapidot, Z., Paz, G., and Rinkevich, B. 2003. Monoclonal antibody specific to urochordate Botryllus schlosseri pyloric gland. Marine Biotechnology. 5:388-394.

Lauzon, R.J., Ishizuka, K.J., and Weissman, I.L. 1992. A cyclical, developmentally-regulated death phenomenon in a colonial urochordate. Developmental Dynamics. 194:71-83.

Lauzon, R.J., Ishizuka, K.J., and Weissman, I.L. 2002. Cyclical generation and degeneration of organs in a colonial urochordate involves crosstalk between old and new: A model for development and regeneration. Developmental Biology. 249:333-348.

Lauzon, R.J., Rinkevich, B., Patton, C.W., and Weissman, I.L. 2000. A morphological study of nonrandom senescence in a colonial urochordate. Biological Bulletin. 198:367-378.

Lin, Y., and Zhan, A. 2016. Population genetic structure and identification of loci under selection in the invasive tunicate, Botryllus schlosseri, using newly developed EST-SSRs. Biochemical Systematics and Ecology. 66:331-336.

Linnaeus, C. 1767. Systema naturae per regna tria naturae, secundum classes, ordines, genera, species, cum characteribus, differentiis, synonymis, locis 12th Edition. Salvius, Stockholm.

Liu, K., Waskow, C., Liu, X., Yao, K., Hoh, J., and Nussenzweig, M. 2007. Origin of dendritic cells in peripheral lymphoid organs of mice. Nature Immunology. 8:578-583.

Locke, A., Hanson, J.M., MacNair, N.G., and Smith, A.H. 2009. Rapid response to non-indigenous species. 2: Case studies of invasive tunicates in Prince Edward Island. Aquatic Invasions. 4:249-258.

López-Legentil, S., Turon, X., and Planes, S. 2006. Genetic structure of the star sea squirt, Botryllus schlosseri, introduced in southern European harbours. Molecular Ecology. 15:3957-3967.

Luisetto, M., Almukthar, N., and Hamid, G.A. 2020. Regeneration abilities of vertebrates and invertebrates and relationship with pharmacological research: Hypothesis of genetic evolution work and micro-environment inhibition role. Journal of Cell Biology and Cell Metabolism. 7:1-21.

Magor, B.G., De Tomaso, A.W., Rinkevich, B., and Weissman, I.L. 1999. Allorecognition in colonial tunicates: Protection against predatory cell lineages? Immunological Revies. 167:69-79.

Manni, L., Anselmi, C., Cima, F., Gasparini, F., Voskoboynik, A., Martini, M., Peronato, A., Burighel, P., Zaniolo, G., and Ballarin, L. 2019. Sixty years of experimental studies on the blastogenesis of the colonial tunicate Botryllus schlosseri. Developmental Biology. 448:293-308.

Manni, L., Gasparini, F., Hotta, K., Ishizuka, K.J., Ricci, L., Tiozzo, S., Voskoboynik, A., and Dauga, D. 2014. Ontology for the asexual development and anatomy of the colonial chordate Botryllus schlosseri. PLoS One. 9:1-15.

Manni, L., Zaniolo, G., and Burighel, P. 1993. Egg envelope cytodifferentiation in the colonial ascidian Botryllus schlosseri (tunicata) Acta Zoologica Stockholm. 74:103-113.

Manni, L., Zaniolo, G., Cima, F., Burighel, P., and Ballarin, L. 2007. Botryllus schlosseri: A model ascidian for the study of asexual reproduction. Developmental Dynamics. 236:335-352.
Martin, J.L., LeGresley, M.M., Thorpe, B., and McCurdy, P. 2011. Non-indigenous tunicates in the Bay of Fundy, eastern Canada (2006-2009). Aquatic Invasions. 6:405-412.

Meenakshi, V.K., and Senthamarai, S. 2006. First report on two species of ascidians to represent the genus Botryllus Gaertner, 1774 from Indian waters. Journal of the Marine Biological Association of India. 48:100-102.

Metschnikow, E. 1869. Entwicklungsgeschichtliche Beiträge. VII. Über die Larven und Knospen von Botryllus. Bulletin de l'Académie impériale des sciences de St.-Pétersbourg. 13:291-293.

Milkman, R. 1967. Genetic and developmental studies on Botryllus schlosseri. Biological Bulletin. 132:229-243.

Milkman, R., and Borgmann, M. 1963. External fertilization of Botryllus schlosseri. Biological Bulletin. 125:385.

Millar, R.H. 1955. On a collection of ascidians from South Africa. Proceedings of the Zoological Society of London. 125:169-221.

Mukai, H. 1977. Comparative studies on the structure of reproductive organs of four botryllid ascidians. Journal of Morphology. 152:363-379.

Mukai, H., and Watanabe, H. 1976. Studies on the formation of germ cells in a compound ascidian Botryllus primigenus Oka. Journal of Morphology. 148:337-362.

Müller, W.E.G., Pancer, Z., and Rinkevich, B. 1994. Molecular cloning and localization of a novel serine protease from the colonial tunicate Botryllus schlosseri. Molecular Marine Biology and Biotechnology. 3:70-77.

Munday, R., Rodriguez, D., Di Maio, A., Kassmer, S., Braden, B., Taketa, D.A., Langenbacher, A., and De Tomaso, A.W. 2015. Aging in the colonial chordate, Botryllus schlosseri. Invertebrate Reproduction and Development. 59:45-50.

Nakashima, K., Sugiyama, J., and Satoh, N. 2008. A spectroscopic assessment of cellulose and the molecular mechanisms of cellulose biosynthesis in the ascidian Ciona intestinalis. Marine Genomics. 1:9-14.

Nakashima, K., Yamada, L., Satou, Y., Azuma, J.I., and Satoh, N. 2004. The evolutionary origin of animal cellulose synthase. Development Genes and Evolution. 214:81-88.

Nydam, M.L., Giesbrecht, K.B., and Stephenson, E.E. 2017. Origin and dispersal history of two colonial ascidian clades in the Botryllus schlosseri species complex. PLoS One. 1:1-30.

Ogasawara, M., Lauro, R.D.I., and Satoh, N. 1999. Ascidian homologs of mammalian thyroid peroxidase genes are expressed in the thyroid-equivalent region of the endostyle. Journal of Experimental Zoology Part B. 285:158-169.

Oka, H., and Watanabe, H. 1957. Colony-specificity in compound ascidians as tested by fusion experiments. Proceedings of the Japan Academy. 33:657-659.

Oka, H., and Watanabe, H. 1960. Problems of colony-specificity in compound ascidians. Bulletin of the Marine Biological Station of Asamushi. 10:153-155.

Oren, M., Douek, J., Fishelson, Z., and Rinkevich, B. 2007. Identification of immune-relevant genes in histoincompatible rejecting colonies of the tunicate Botryllus schlosseri. Developmental \& Comparative Immunology. 31:889-902.

Oren, M., Paz, G., Douek, J., Rosner, A., Amar, K.O., and Rinkevich, B. 2013. Marine invertebrates cross phyla comparisons reveal highly conserved immune machinery. Immunobiology. 218:484-495.

Oren, M., Paz, G., Douek, J., Rosner, A., Fishelson, Z., Goulet, T.L., Henckel, K., and Rinkevich, B. 2010. "Rejected" vs. 
"rejecting" transcriptomes in allogeneic challenged colonial urochordates. Molecular Immunology. 47:2083-2093.

Orensanz, J.M., Schwindt, E., Pastorino, G., Bortolus, A., Casas, G., Darrigran, G., Elías, R., López Gappa, J.J., Obenat, S., Pascual, M., Penchaszadeh, P., Piriz, M.L., Scarabino, F., Spivak, E.D., and Vallarino, E.A. 2002. No longer the pristine confines of the world ocean: A survey of exotic marine species in the Southwestern Atlantic. Biological Invasions. 4:115-143.

Pallas, P.S. 1766. Elenchus zoophytorum sistens generum adumbrationes generaliores et specierum cognitarum succinctas descriptiones cum selectis auctorum synonymis. van Cleef, The Hague.

Pancer, Z., Gershon, H., and Rinkevich, B. 1995. Coexistence and possible parasitism of somatic and germ cell lines in chimeras of the colonial urochordate Botryllus schlosseri. Biological Bulletin. 189:106-112.

Paz, G., Douek, J., Mo, C., Goren, M., and Rinkevich, B. 2003. Genetic structure of Botryllus schlosseri (Tunicata) populations from the Mediterranean coast of Israel. Marine Ecology Progress Series. 250:153-162.

Pérez-Portela, R., Bishop, J.D.D., Davis, A.R., and Turon, X. 2009. Phylogeny of the families Pyuridae and Styelidae (Stolidobranchiata, Ascidiacea) inferred from mitochondrial and nuclear DNA sequences. Molecular Phylogenetics and Evolution. 50:560-570.

Pizon, A. 1893. Histoire de la blastogénèse chez les Botryllides. Annales des sciences naturelles Series 7. 14:1-386.

Qarri, A., Rosner, A., Rabinowitz, C., and Rinkevich, B. 2020. UV-B radiation bearings on ephemeral soma in the shallow water tunicate Botryllus schlosseri. Ecotoxicology and Environmental Safety. 196:110489.

Rabinowitz, C., Alfassi, G., and Rinkevich, B. 2009. Further portrayal of epithelial monolayers emergent de novo from extirpated ascidians palleal buds. In Vitro Cellular \& Developmental Biology - Animal. 45:334-342.

Rabinowitz, C., and Rinkevich, B. 2003. Epithelial cell cultures from Botryllus schlosseri palleal buds: Accomplishments and challenges. Methods in Cell Science. 25:137-148.

Rabinowitz, C., and Rinkevich, B. 2004. In vitro delayed senescence of extirpated buds from zooids of the colonial tunicate Botryllus schlosseri. Journal of Experimental Biology. 207:1523-1532.

Rabinowitz, C., and Rinkevich, B. 2011. De novo emerged stemness signatures in epithelial monolayers developed from extirpated palleal buds. In Vitro Cellular and Developmental Biology-Animal. 47:26-31.

Reem, E., Douek, J., Katzir, G., and Rinkevich, B. 2013a. Longterm population genetic structure of an invasive urochordate: The ascidian Botryllus schlosseri. Biological Invasions. 15:225-241.

Reem, E., Douek, J., Paz, G., Katzir, G., and Rinkevich, B. 2017. Phylogenetics, biogeography and population genetics of the ascidian Botryllus schlosseri in the Mediterranean Sea and beyond. Molecular Phylogenetics and Evolution. 107:221-231.

Reem, E., Mohanty, I., Katzir, G., and Rinkevich, B. 2013b. Population genetic structure and modes of dispersal for the colonial ascidian Botryllus schlosseri along the Scandinavian Atlantic coasts. Marine Ecology Progress Series. 485:143-154.

Renier, S.A. 1793. Sopra il Botrillo piantanimale marino. Opuscoli scelti sulle scienze e sulle arti. Milano. 4:256-267.
Ricci, L., Cabrera, F., Lotito, S., and Tiozzo, S. 2016a. Redeployment of germ layers related TFs shows regionalized expression during two non-embryonic developments. Developmental Biology. 416:235-248.

Ricci, L., Chaurasia, A., Lapébie, P., Dru, P., Helm, R.R., Copley, R.R., and Tiozzo, S. 2016b. Identification of differentially expressed genes from multipotent epithelia at the onset of an asexual development. Scientific Reports. 6:1-10.

Richmond, P.A. 1991. Occurrence and functions of native cellulose. In Biosynthesis and Biodegradation of Cellulose, eds. Haigler, C.H., and Weimer, P.J. 5-23. Marcel Dekker, Inc., New York.

Rinkevich, B. 1992. Aspects of the incompatibility in botryllid ascidians. Animal Biology. 1:17-28.

Rinkevich, B. 1993. Immunological resorption in Botryllus schlosseri (Tunicata) chimeras is characterized by multilevel hierarchical organization of histocompatibility alleles: A speculative endeavor. Biological Bulletin. 184:342-345.

Rinkevich, B. 1995. Morphologically related allorecognition assays in botryllid ascidians. In Techniques in Fish Immunology. 4: Immunology and Pathology of Aquatic Invertebrates, eds. Stolen, J.S., Fletcher, T.C., Smith, S.A., Zelikoff, J.T., Kaattari, S.L., Anderson, R.S., Söderhäll, K., and WeeksPerkins, B.A. 17-21. SOS Publications, Fair Haven, NJ.

Rinkevich, B. 1996. Bi-versus multichimerism in colonial urochordates: A hypothesis for links between natural tissue transplantation, allogenetics and evolutionary ecology. Experimental and Clinical Immunogenetics. 13:61-69.

Rinkevich, B. 1999a. Invertebrates versus vertebrates innate immunity: In the light of evolution. Scandinavian Journal of Immunology. 50:456-460.

Rinkevich, B. 1999b. Cell cultures from marine invertebrates: Obstacles, new approaches and recent improvements. Journal of Biotechnology. 70:133-153.

Rinkevich, B. 2002a. The colonial urochordate Botryllus schlosseri: From stem cells and natural tissue transplantation to issues in evolutionary ecology. Bio Essays. 24:730-740.

Rinkevich, B. 2002b. Germ cell parasitism as an ecological and evolutionary puzzle: Hitchhiking with positively selected genotypes. Oikos. 96:25-30.

Rinkevich, B. 2004a. Primitive immune systems: Are your ways my ways? Immunological Reviews. 198:25-35.

Rinkevich, B. 2004b. Will two walk together, except they have agreed? Journal of Evolutionary Biology. 17:1178-1179.

Rinkevich, B. 2005a. Rejection patterns in botryllid ascidian immunity: The first tier of allorecognition. Canadian Journal of Zoology. 83:101-121.

Rinkevich, B. 2005b. Natural chimerism in colonial urochordates. Journal of Experimental Marine Biology and Ecology. 322:93-109.

Rinkevich, B. 2005c. Marine invertebrate cell cultures: New millennium trends. Marine Biotechnology. 7:429-439.

Rinkevich, B. 2011a. Quo vadis chimerism? Chimerism. 2:1-5.

Rinkevich, B. 2011b. Cell cultures from marine invertebrates: New insights for capturing endless stemness. Marine Biotechnology. 13:345-354.

Rinkevich, B. 2017. Senescence in modular animals: Botryllid ascidians as a unique aging system. In The Evolution of Senescence in the Tree of Life, eds. Salguero-Gomez, R., Shefferson, R., and Jones, O. 220-237. Cambridge University Press, Cambridge.

Rinkevich, B. 2019. The tail of the underwater phoenix. Developmental Biology. 448:291-292. 
Rinkevich, B., Lauzon, R.J., Brown, B.W.M., and Weissman, I.L. 1992b. Evidence for a programmed life span in a colonial protochordate. Proceedings of the National Academy of Sciences of the United States of America. 89:3546-3550.

Rinkevich, B., Porat, R., and Goren, M. 1998a. Ecological and life history characteristics of Botryllus schlosseri (Tunicata) populations inhabiting undersurface shallow-water stones. Marine Ecology. 19:129-145.

Rinkevich, B., Porat, R., and Goren, M. 1998b. On the development and reproduction of Botryllus schlosseri (Tunicata) colonies from the eastern Mediterranean Sea: Plasticity of life history traits. Invertebrate Reproduction \& Development. 34:207-218.

Rinkevich, B., Paz, G., Douek, J., and Ben-Shlomo, R. 2001. Allorecognition and microsatellite allele polymorphism of Botryllus schlosseri from the Adriatic Sea. In The Biology of Ascidians, eds. Sawada H., Yokosawa H., Lambert C.C. 426-435. Springer, Tokyo.

Rinkevich, B., and Rabinowitz, C. 1994. Acquiring embryo-derived cell cultures and aseptic metamorphosis of larvae from the colonial protochordate Botryllus schlosseri. Invertebrate Reproduction \& Development. 25:59-72.

Rinkevich, B., and Rabinowitz, C. 1997. Initiation of epithelial cell cultures from palleal buds of Botryllus schlosseri, a colonial tunicate. In Vitro Cellular \& Developmental Biology Animal. 33:422-424.

Rinkevich, B., and Rinkevich, Y. 2013. The "stars and stripes" metaphor for animal regeneration-elucidating two fundamental strategies along a continuum. Cells. 2:1-18.

Rinkevich, B., and Saito, Y. 1992. Self-nonself recognition in the colonial protochordate Botryllus schlosseri from Mutsu Bay, Japan. Zoological Science. 9:983-988.

Rinkevich, B., Saito, Y., and Weissman, I.L. 1993. A colonial invertebrate species that displays a hierarchy of allorecognition responses. Biological Bulletin. 184:79-86.

Rinkevich, B., and Shapira, M. 1998. An improved diet for inland broodstock and the establishment of an inbred line from Botryllus schlosseri, a colonial sea squirt (Ascidiacea). Aquatic Living Resources. 11:163-171.

Rinkevich, B., Shapira, M., Weissman, I.L., and Yasunory, S. 1992a. Allogeneic responses between three remote populations of the cosmopolitan ascidian Botryllus schlosseri. Zoological Science. 9:989-994.

Rinkevich, B., and Weissman, I.L. 1987a. A long-term study on fused subclones in the ascidian Botryllus schlosseri: The resorption phenomenon (Protochordata: Tunicata). Journal of Zoology. 213:717-733.

Rinkevich, B., and Weissman, I.L. 1987b. Chimeras in colonial invertebrates: A synergistic symbiosis or somatic- and germcell parasitism? Symbiosis. 4:117-134.

Rinkevich, B., and Weissman, I.L. 1987c. The fate of Botryllus (Ascidiacea) larvae cosettled with parental colonies: Beneficial or deleterious consequences? Biological Bulletin. 173:474-488.

Rinkevich, B., and Weissman, I.L. 1988. Retreat growth in the ascidian Botryllus schlosseri: The consequences of non-self recognition. In Invertebrate Historecognition, ed. Grosberg, R.K. 93-109. Plenum Press, New York.

Rinkevich, B., and Weissman, I.L. 1989. Variation in the outcomes following chimera formation in the colonial tunicate Botryllus schlosseri. Bulletin of Marine Science. 45:213-227.

Rinkevich, B., and Weissman, I.L. 1990. Botryllus schlosseri (Tunicata) whole colony irradiation: Do senescent zooid resorption and immunological resorption involve similar recognition events? Journal of Experimental Zoology. 253:189-201.

Rinkevich, B., and Weissman, I.L. 1991. Interpopulational allogeneic reactions in the colonial protochordate Botryllus schlosseri. International Immunology. 3:1265-1272.

Rinkevich, B., and Weissman, I.L. 1992a. Chimeras vs genetically homogeneous individuals: Potential fitness costs and benefits. Oikos. 63:119-124.

Rinkevich, B., and Weissman, I.L. 1992b. Allogeneic resorption in colonial protochordates: Consequences of nonself recognition. Developmental \& Comparative Immunology. 16:275-286.

Rinkevich, B., and Weissman, I.L. 1998. Transplantation of Fu/ HC-incompatible zooids in Botryllus schlosseri results in chimerism. Biological Bulletin. 195:98-106.

Rinkevich, B., Weissman, I.L., and Shapira, M. 1994. Alloimmune hierarchies and stress-induced reversals in the resorption of chimeric protochordate colonies. Proceedings of the Royal Society of London Series B. 258:215-220.

Rinkevich, B., and Yankelevich, I. 2004. Environmental split between germ cell parasitism and somatic cell synergism in chimeras of a colonial urochordate. Journal of Experimental Biology. 207:3531-3536.

Rinkevich, Y., Matranga, V., and Rinkevich. B. 2009. Stem cells in aquatic invertebrates: Common premises and emerging unique themes. In Stem Cells in Marine Organisms, eds. Rinkevich, B., and Matranga, B. 60-103. Springer, the Netherlands.

Rinkevich, Y., Voskoboynik, A., Rosner, A., Rabinowitz, C., Paz, G., Oren, M., Douek, J., Alfassi, G., Moiseeva, E., Ishizuka, K.J., Palmeri, K.J., and Weissman, I.L. 2013. Repeated, longterm cycling of putative stem cells between niches in a basal chordate. Developmental Cell. 24:76-88.

Rodriguez, D., Kassmer, S.H., and De Tomaso. A.W. 2016. Gonad development and hermaphroditism in the ascidian Botryllus schlosseri. Molecular Reproduction \& Development. 84: 158-170.

Rodriguez, D., Sanders, E.N., Farell, K., Langenbacher, A.D., Taketa, D.A., Hopper, M.R., Kennedy, M., Gracey, A., and De Tomaso, A.W. 2014. Analysis of the basal chordate Botryllus schlosseri reveals a set of genes associated with fertility. BMC Genomics. 15:1183.

Rondelet, G. 1555. Universae aquatilium historiae pars altera, cum veris ipsorum imaginibus. M Bonhomme, Lugduni.

Rosental, B., Kowarsky, M., Seita, J., Corey, D.M., Ishizuka, K.J., Palmeri, K.J., Chen, S., Sinha, R., Okamoto, J., Mantalas, G., Manni, L., Raveh, T., Clarke, D.N., Quake, S.R., Weissman, I.L., Tsai, J.M., Newman, A.M., Neff, N.F., and Garry, P. 2018. Complex mammalian-like haematopoietic system found in a colonial chordate. Nature. 564:425-429.

Rosner, A., Alfassi, G., Moiseeva, E., Paz, G., Rabinowitz, C., Lapidot, Z., Douek, J., Haim, A., and Rinkevich, B. 2014. The involvement of three signal transduction pathways in botryllid ascidian astogeny, as revealed by expression patterns of representative genes. International Journal of Developmental Biology. 58:677-692.

Rosner, A., Kravchenko, O., and Rinkevich, B. 2019. IAP genes partake weighty roles in the astogeny and whole body regeneration in the colonial urochordate Botryllus schlosseri. Developmental Biology. 448:320-341.

Rosner, A., Moiseeva, E., Rabinowitz, C., and Rinkevich, B. 2013. Germ lineage properties in the urochordate Botryllus schlosseri: From markers to temporal niches. Developmental Biology. 384:356-374. 
Rosner, A., Paz, G., and Rinkevich, B. 2006. Divergent roles of the DEAD-box protein BS-PL10, the urochordate homologue of human DDX3 and DDX3Y proteins, in colony astogeny and ontogeny. Developmental Dynamics. 235:1508-1521.

Rosner, A., Rabinowitz, C., Moiseeva, E., Voskoboynik, A., and Rinkevich, B. 2007. BS-cadherin in the colonial urochordate Botryllus schlosseri: One protein, many functions. Developmental Biology. 304:687-700.

Rosner, A., and Rinkevich, B. 2007. The DDX3 subfamily of the DEAD box helicases: Divergent roles as unveiled by studying different organisms and in vitro assays. Current Medicinal Chemistry. 14:2517-2525.

Ruppert, E.E., Fox, R.S., and Barnes, R.D. 2004. Chapter 29: Chordata. In Invertebrate Zoology: A Functional Evolutionary Approach. Vol. 6, 941-951. Saunders College Publishing, New York.

Sabbadin, A. 1955. Osservazioni sullo sviluppo, l'accrescimento e la riproduzione di Botryllus schlosseri (Pallas) in condizioni di laboratorio. Bollettino di. Zoologia. 22:243-263.

Sabbadin, A. 1962. Le basi genetiche della capacità di fusione fra colonie in Botryllus schlosseri (Ascidiacea). Rendiconti Accademia Nazionale dei Lincei. 32:1031-1035.

Sabbadin, A. 1971. Self- and cross-fertilization in the compound ascidian Botryllus schlosseri. Developmental Biology. 24:379-391.

Sabbadin, A. 1977.Linkage between two loci controlling colour polymorphism in the colonial ascidian, Botryllus schlosseri. Experientia. 33:876-877.

Sabbadin, A., and Astorri, C. 1988. Chimeras and histocompatibility in the colonial ascidian Botryllus schlosseri. Developmental \& Comparative Immunology. 12:737-747.

Sabbadin, A., and Zaniolo, G. 1979. Sexual differentiation and germ cell transfer in the colonial ascidian Botryllus schlosseri. Journal of Experimental Zoology. 207:289-304.

Sabbadin, A., Zaniolo, G., and Majone, F. 1975. Determination of polarity and bilateral asymmetry in palleal and vascular buds of the ascidian Botryllus schlosseri. Developmental Biology. 46:79-87.

Savigny, J.C. 1816. Mémoires sur les animaux sans vertèbres 2. Doufour, Paris.

Schlosser, J.A., and Ellis, J. 1756. An account of a curious, fleshy, coral-like substance: In a letter to Mr. Peter Collinson, F. R. S. from Dr. John Albert Schlosser M. D. F. R. S. with some observations on it communicated to Mr. Collinson by $\mathrm{Mr}$. John Ellis, F. R. S. Philosophical Transections. 49:449-452.

Scofield, V.L., Schlumpberger, J.M., West, L.A., and Weissman, I.L. 1982. Protochordate allorecognition is controlled by a MHC-like gene system. Nature. 295:499-502.

Simon-Blecher, N. 2003. Aspects of allorecognition in botryllid ascidians. PhD dissertation, Faculty of Life Sciences, Bar Ilan Univerity, Israel.

Simon-Blecher, N., Achituv, Y., and Rinkevich, B. 2004. Protochordate concordant xenotransplantation settings reveal outbreaks of donor cells and divergent life span traits. Developmental \& Comparative Immunology. 28:983-991.

Singer, M.A. 2016. Stem cells and aging. Stem Cell \& Translational Investigation. 3:1-8.

Smith, M.J., and Dehnel, P.A. 1971. The composition of tunic from four species of ascidians. Comperative Biochemistry \& Physiology Part B: Comparative Biochemistry. 40:615-622.

Spallanzani, L. 1784. Giornale di esperienze sulla fauna marina della laguna di Chioggia. Biblioteca Digitale Reggiana. Mss. Reggio. B57.
Stewart-Savage, J., Phillippi, A., and Yund, P.O. 2001. Delayed insemination results in embryo mortality in a brooding ascidian. Biological Bulletin. 201:52-58.

Stoner, D.S., Ben-Shlomo, R., Rinkevich, B., and Weissman, I.L. 2002. Genetic variability of Botryllus schlosseri invasions to the east and west coasts of the USA. Marine Ecology Progress Series. 243:93-100.

Stoner, D.S., Rinkevich, B., and Weissman, I.L. 1999. Heritable germ and somatic cell lineage competitions in chimeric colonial protochordates. Proceedings of the Nationall Academy of Sciences of the United States of America. 96:9148-9153.

Stoner, D.S., and Weissman, I.L. 1996. Somatic and germ cell parasitism in a colonial ascidian: Possible role for a highly polymorphic allorecognition system. Proceedings of the Nationall Academy of Sciences of the United States of America. 93:15254-15259.

Taneda, Y., Saito, Y., and Watanabe, H. 1985. Self or non-self discrimination in ascidians. Zoological Science. 2:433-442.

Taneda, Y., and Watanabe, H. 1982a. Studies on colony specificity in the compound ascidian, Botryllus primigenus Oka. 1: Initiation of "nonfusion" reaction with special reference to blood cells infiltration. Developmental \& Comparative Immunology. 6:43-52.

Taneda, Y., and Watanabe, H. 1982b. Effects of X-irradiation on colony specificity in the compound ascidian, Botryllus primigenus Oka. Developmental \& Comparative Immunology. 6:665-673.

Tiozzo, S., Christiaen, L., Deyts, C., Manni, L., Joly, J.S., and Burighel, P. 2005. Embryonic versus blastogenetic development in the compound ascidian Botryllus schlosseri: Insights from Pitx expression patterns. Developmental Dynamics. 232:468-478.

Tiozzo, S., and De Tomaso, A.W. 2009. Functional analysis of Pitx during asexual regeneration in a basal chordate. Evolutionary Development. 11:152-162.

Van Name, W.G. 1945. The North and South American ascidians. $B$ Am Mus Mat Hist. 84.

Vogt, G. 2012. Hidden treasures in stem cells of indeterminately growing bilaterian invertebrates. Stem Cell Reviews and Reports. 8:305-317.

Volpe, E.P., and Earley, E.M. 1970. Somatic cell mating and segregation in chimeric frogs. Science. 168:850-852.

Voskoboynik, A., Neff, N.F., Sahoo, D., Newman, A.M., Pushkarev, D., Koh, W., Passarelli, B., Fan, H.C., Mantalas, G.L., Palmeri, K.J., Ishizuka, K.J., Gissi, C., Griggio, F., Ben-Shlomo, R., Corey, D.M., Penland, L., White, R.A., Weissman, I.L., and Quake, S.R. 2013a. The genome sequence of the colonial chordate, Botryllus schlosseri. eLife. 2:1-24.

Voskoboynik, A., Newman, A.M., Corey, D.M., Sahoo, D., Pushkarev, D., Neff, N.F., Passarelli, B., Koh, W., Ishizuka, K.J., Palmeri, K.J., Dimov, I.K., Keasar, C., Fan, H.C., Mantalas, G.L., Sinha, R., Penland, L., Quake, S.R., and Weissman, I.L. 2013b. Identification of a colonial chordate histocompatibility gene. Science. 341:384-387.

Voskoboynik, A., Reznick, A.Z., and Rinkevich, B. 2002. Rejuvenescence and extension of an urochordate life span following a single, acute administration of an anti-oxidant, butylated hydroxytoluene. Mechanisms of Ageing and Development. 123:1203-1210.

Voskoboynik, A., Rinkevich, B., Weiss, A., Moiseeva, E., and Reznick, A.Z. 2004. Macrophage involvement for successful degeneration of apoptotic organs in the colonial urochordate Botryllus schlosseri. Journal of Experimental Biology. 207:2409-2416. 
Voskoboynik, A., Rinkevich, B., and Weissman, I.L. 2009. Stem cells, chimerism and tolerance: Lessons from mammals and ascidians. In Stem Cells in Marine Organisms, eds. Rinkevich, B., and Matranga, B. 281-308. Springer, the Netherlands.

Voskoboynik, A., Simon-Blecher, N., Soen, Y., Rinkevich, B., De Tomaso, A.W., Ishizuka, K.J., and Weissman, I.L. 2007. Striving for normality: Whole body regeneration through a series of abnormal generations. FASEB Journal.21:1335-1344.

Voskoboynik, A., Soen, Y., Rinkevich, Y., Rosner, A., Ueno, H., Reshef, R., Ishizuka, K.J., Palmeri, K.J., Moiseeva, E., Rinkevich, B., and Weissman, I.L. 2008. Identification of the endostyle as a stem cell niche in a colonial chordate. Cell Stem Cell. 3:456-464.

Voskoboynik, A., and Weissman, I.L. 2015. Botryllus schlosseri, an emerging model for the study of aging, stem cells, and mechanisms of regeneration. Invertebrate Reproduction \& Development. 59:33-38.

Watanabe, H. 1953. Studies on the regulation in fused colonies in Botryllus primigenus (Ascidiae Compositae). Science reports of the Tokyo Bunrika Daigaku. Section B. 7:183-198.

Watterson, R.L. 1945. Asexual reproduction in the colonial tunicate, Botryllus schlosseri (pallas) savigny, with special reference to the developmental history of intersiphonal bands of pigment cells. Biological Bulletin. 88:71-103.

Weissman, I.L. 2015. Stem cells are units of natural selection for tissue formation, for germline development, and in cancer development. Proceedings of the National Academy of Sciences of the United States of America. 112:8922-8928.

Weissman, I.L., Saito, Y., and Rinkevich, B. 1990. Allorecognition histocompatibility in a protochordate species: Is the relationship to MHC somatic or structural? Immunological Reviews. 113:227-241.

Yaguchi, T., Aida, S., Kaul, S.C., and Wadhwa, R. 2007. Involvement of mortalin in cellular senescence from the perspective of its mitochondrial import, chaperone, and oxidative stress management functions. Annals of the New York Academy of Sciences. 1100:306-311.

Yokoyama, K., Fukumoto, K., Murakami, T., Harada, S., Hosono, R., Wadhwa, R., Mitsui, Y., and Ohkuma, S. 2002. Extended longevity of Caenorhabditis elegans by knocking in extra copies of hsp70F, a homolog of mot-2 (mortalin)/mthsp70/ Grp75. FEBS Letters. 516:53-57.

Yund, P.O., Collins, C., and Johnson, S.L. 2015. Evidence of a native Northwest Atlantic COI Haplotype clade in the cryptogenic colonial ascidian Botryllus schlosseri. Biological Bulletin. 228:201-216.

Zaniolo, G. 1981. Histology of the ascidian Botryllus schlosseri tunic: In particular, the test cells. Italian Journal of Zoology. 48:169-178.

Zaniolo, G., Burighel, P., and Martinucci, G. 1987. Ovulation and placentation in Botryllus schlosseri (ascidiacea): An ultrastructural study. Canadian Journal of Zoology. 65:1181-1190. 